\title{
Adaptive immunity in the liver
}

\author{
Zongwen Shuai ${ }^{1,2}$, Miranda WY Leung ${ }^{1}$, Xiaosong He ${ }^{1}$, Weici Zhang ${ }^{1}$, Guoxiang Yang ${ }^{1}$, \\ Patrick SC Leung ${ }^{1}$ and M Eric Gershwin ${ }^{1}$
}

The anatomical architecture of the human liver and the diversity of its immune components endow the liver with its physiological function of immune competence. Adaptive immunity is a major arm of the immune system that is organized in a highly specialized and systematic manner, thus providing long-lasting protection with immunological memory. Adaptive immunity consists of humoral immunity and cellular immunity. Cellular immunity is known to have a crucial role in controlling infection, cancer and autoimmune disorders in the liver. In this article, we will focus on hepatic virus infections, hepatocellular carcinoma and autoimmune disorders as examples to illustrate the current understanding of the contribution of $\mathrm{T}$ cells to cellular immunity in these maladies. Cellular immune suppression is primarily responsible for chronic viral infections and cancer. However, an uncontrolled auto-reactive immune response accounts for autoimmunity. Consequently, these immune abnormalities are ascribed to the quantitative and functional changes in adaptive immune cells and their subsets, innate immunocytes, chemokines, cytokines and various surface receptors on immune cells. A greater understanding of the complex orchestration of the hepatic adaptive immune regulators during homeostasis and immune competence are much needed to identify relevant targets for clinical intervention to treat immunological disorders in the liver.

Cellular \& Molecular Immunology (2016) 13, 354-368; doi:10.1038/cmi.2016.4; published online 21 March 2016

Keywords: adaptive immunity; T cells; immunopathogenesis; antiviral immunity

\section{INTRODUCTION}

The liver is one of the most vital organs in the human body and has specific physiological functions and a unique anatomical architecture. Blood circulates through the liver via the hepatic artery and portal vein. The hepatic artery shares arterial functions with other organs, whereas the hepatic portal vein contains a myriad of absorbed nutrients, microbial products and drugs from the gastrointestinal tract and spleen, some of which may be potential antigens. Before entering systemic circulation, the blood in the portal vein must be filtered through the liver, which is required to perform extensive metabolic functions and exert powerful immunocompetence, thus acting as a strong protective barrier between the portal vein and the systemic circulation. In fact, the liver is also known as 'lymphoid liver' because it harbors a large number of immune cells, such as leukocytes, dendritic cells (DCs), natural killer cells, T- and B cells. Moreover, in inflammation, some hepatic parenchymal cells may act as proinflammatory cells, as exemplified by hepatocytes and cholangiocytes. ${ }^{1}$ From the perspective of the hepatic microenvironment, the architecture of the liver sinusoid is specifically designed to lack a basement membrane and to exhibit a very slow blood flow, which is conducive to the aggregation of various pathogens, oncocytes and immunocytes. These immunocytes are responsible for innate immunity and adaptive immunity to protect the human body from infections, tumors and even autoantigens in autoimmune liver diseases (AILDs) through highly orchestrated mechanisms. ${ }^{2-5}$ In this review, we will focus on adaptive immunity and discuss ${ }^{1}$ the major $\mathrm{T}$-cell subgroups and their functions, and ${ }^{2}$ the current understanding of the role of $\mathrm{T}$ cells in hepatic infections, liver tumors and AILDs, with a particular emphasis on common hepatic diseases, including viral infections (hepatitis B and C), hepatocellular carcinoma (HCC), primary biliary cholangitis (PBC) and autoimmune hepatitis (AIH), to illustrate the complexity and challenges in these rapidly developing fields.

\footnotetext{
${ }^{1}$ Division of Rheumatology, Allergy and Clinical Immunology, University of California Davis School of Medicine, Davis, CA 95616, USA and ${ }^{2}$ Department of Rheumatology and Immunology, The First Affiliated Hospital of Anhui Medical University, Hefei 230022, China.

Correspondence: M Eric Gershwin, M.D., Division of Rheumatology, Allergy and Clinical Immunology, University of California Davis School of Medicine, 451 Health Sciences Drive, Suite 6510, Davis, CA 95616, USA.

Email: megershwin@ucdavis.edu

Received: 19 November 2015; Revised: 6 January 2016; Accepted: 9 January 2016
} 
MAJOR SUBSETS OF T CELLS AND THEIR FUNCTIONS IN ADAPTIVE IMMUNITY

On the basis of their phenotypes and functions, the major T lymphocytes that are involved in adaptive immunity include CD4 $\mathrm{T}$ cells, CD8 $\mathrm{T}$ cells and $\gamma \delta-\mathrm{T}$ cells, which are further categorized into several subsets (Table 1). CD4 T cells have at least five functional subsets, including helper $\mathrm{T}(\mathrm{Th}) 1$, Th2, Th17 and follicular helper $\mathrm{T}$ (Tfh) cells, which tend to promote innate and adaptive immune responses, and the T-regulatory (Treg) cells, which usually suppress the inflammation resulting from innate and adaptive immunity. CD8 T cells are composed of the following two subgroups: cytotoxic $\mathrm{T}$ cells (Tc), which are the main cell killer in adaptive immunity, and CD8 Treg cells, which inhibit the activity of Th cells and suppress immune responses to infection. $\gamma \delta$-T cells participate in both innate and adaptive immunity. Their function involves not only immune effector pathways, that is, phagocytosis and tumor killing, but also immune regulation, as exemplified by the suppression of CD8 $\mathrm{T}$ cells (Table 1). In adaptive immunity in the liver, these T-cell subsets are highly orchestrated in terms of their roles and specific functions at each stage of various disorders. ${ }^{4,6}$ To illustrate this, we will examine several representative hepatic diseases including infections, neoplasms and AILDs.

\section{ADAPTIVE IMMUNITY IN HEPATIC VIRAL INFECTIONS}

Hepatitis B virus (HBV) and hepatitis $\mathrm{C}$ virus (HCV) infections are two of the most common chronic liver infections, which often lead to hepatic cirrhosis and HCC. In the United States, the prevalence of HBV and HCV infections is 4.9 and $1.8 \%$, respectively. ${ }^{6}$ Although HBV and HCV are both hepatotropic viruses, the real 'culprit' that accounts for the hepatocellular necrosis in HBV or HCV infection is primarily the adaptive immune response to virus-infected liver cells. ${ }^{7}$

Naive $\mathrm{T}$ cells that are specific for viral antigens can be activated locally in the liver. Conventionally, at the initiation stage of adaptive immunity, antigen-specific naive $\mathrm{T}$ cells are usually primed by antigen-presenting cells (APCs) in the lymph nodes and other lymphoid organs, where they proliferate, differentiate into effector cells and then migrate to the target site (such as the liver) to execute their effector functions. ${ }^{8}$ However, HBV-specific naive $\mathrm{T}$ cells can directly enter the liver, be primed and exhibit the anti-HBV effects. ${ }^{9}, 10$ The liver also houses abundant APCs, such as myeloid DCs, plasmacytoid DCs, Kupffer cells, liver sinusoidal endothelial cells, hepatocytes and stellate cells. ${ }^{11,12}$ In addition, activated platelets may promote the recruitment of HBV-specific CD8 T cells into liver, which can result in hepatic impairment of cytotoxic $\mathrm{T}$ cells, which normally clear the virus. ${ }^{13}$

\section{T-cell responses in HBV infection}

CD4 T cells in HBV infection. Different subsets of CD4 T cells have various immunopathological roles during HBV infection. In patients with HBV, the number of Th17 cells is significantly increased in the blood and liver, and is accompanied by elevated levels of interleukin (IL)-17 and IL-22 in the blood. ${ }^{14}$ The roles of $\mathrm{T}$ cells and T-cell subsets have been investigated in animal models and clinical samples from patients with HBV. Adoptive transfer of spleen cells from HBV-immunized mice into HBV transgenic (Tg) mice exacerbates hepatic damage. However, the damage is markedly decreased by IL-22 inhibition. Because IL-22 is primarily produced by Th17 cells, these data support the hypothesis that Th17 cells have the potential to exacerbate liver lesions during HBV infection. ${ }^{15}$ The immunomodulatory effects of $\mathrm{CD} 4^{+}$

Table $1 \mathrm{~T}$-cell subsets and their functions in adaptive immunity

\begin{tabular}{|c|c|c|c|}
\hline Cell group & Subset & Function & Reference \\
\hline \multirow[t]{3}{*}{$\begin{array}{l}\text { CD4 } \\
\text { T cells }\end{array}$} & Th1 & $\begin{array}{l}\text { Secretion of IFN- } \gamma \text {, IL-2, TNF- } \alpha \text {; activation of CD8 T cells; induction of Ig class switching to complement- } \\
\text { fixing antibodies; cell-mediated and delayed-type hypersensitivity responses }\end{array}$ & 186,187 \\
\hline & Th17 & Secretion of cytokines IL-17, IL-21, IL-22, IFN- $\gamma$; suppression of Treg cell function & $15,42,167,187,189,190$ \\
\hline & Treg & $\begin{array}{l}\text { Secretion of IL-10 and TGF- } \beta \text {; inhibition of Th17 proliferation and secretion of IL-17; suppression of } \\
\text { proliferation of CD4 CD25(-)T, CD8 T cells and their secretion of IFN- } \gamma \text {; suppression of innate immunity }\end{array}$ & $165,173,193,194$ \\
\hline \multirow[t]{2}{*}{$\begin{array}{l}\text { CD8 } \\
\text { T cells }\end{array}$} & Tc & $\begin{array}{l}\text { Secretion of granzymes, perforin, IFN- } \gamma \text {, TNF- } \alpha \text {, IL-4, IL-5, IL-9, IL-10, IL-13, IL-17 and IL-21; cytotoxicity } \\
\text { against tumors and intracellular pathogens; promotion of Th2-mediated allergy; propagation of autoimmunity }\end{array}$ & 195,196 \\
\hline & $\begin{array}{l}\text { CD8 } \\
\text { Treg }\end{array}$ & $\begin{array}{l}\text { Secretion of granzymes, perforin, TGF- } \beta \text { and IL-10; suppression of proliferation of Th cells; suppression of } \\
\text { immunity in response to infection }\end{array}$ & $54,197,198$ \\
\hline
\end{tabular}

Abbreviations: IFN- $\gamma$, interferon $\gamma$; Ig, immunoglobulin; IL, interleukin; Tc, cytotoxic T cell; Tfh, follicular helper T cell; TGF- $\beta$, transforming growth factor- $\beta$; Th, helper T cell; TNF- $\alpha$, tumor necrosis factor $\alpha$; Treg, regulatory T cell. 
$\mathrm{CD}^{+} 5^{+}$Tregs on HBV have received significant attention. Several studies have demonstrated an immunosuppressive effect of $\mathrm{HBV}$-specific $\mathrm{CD} 4^{+} \mathrm{CD} 25^{+}$foxp $3^{+}$Treg cells during HBV infection. For example, such cells from chronic HBV patients suppress HBV-mediated interferon- $\gamma$ (IFN- $\gamma$ ) production and the proliferation of autologous peripheral blood mononuclear cells. ${ }^{16}$ In addition, the number of $\mathrm{CD} 4{ }^{+} \mathrm{CD} 25^{+}$ Foxp $3^{+}$Treg cells is increased in the peripheral blood and liver from $\mathrm{HBV}$-associated acute-on-chronic liver failure and inhibits the proliferation of autologous $\mathrm{CD} 4^{+} \mathrm{CD} 25^{-}$Th cells in vitro. ${ }^{17}$

CD8 $T$ cells in HBV infection. Accumulating evidence demonstrates that $\mathrm{HBV}$-specific CD8 $\mathrm{T}$ cells have a fundamental role in viral clearance and in the prognosis of $\mathrm{HBV}$ infection. Thimme et al. ${ }^{18}$ have compared the consequences of CD4 T deletion with CD8 $\mathrm{T}$ deletion in $\mathrm{HBV}$-infected chimpanzees and have demonstrated that the CD8 T cells are responsible for both noncytolytic and cytolytic anti-HBV functions in acute hepatitis $\mathrm{B}$. In the noncytolytic process, naive CD8 T cells (primed in the liver) or activated CD8 $\mathrm{T}$ cells (primed in the extrahepatic lymphatic tissues) migrate into the liver. Once in the liver, the HBV-specific CD8 T cells and HBV-nonspecific innate immunocytes (macrophages) become activated and produce IFN- $\gamma$ and tumor necrosis factor- $\alpha$ (TNF- $\alpha$ ), which, in turn, noncytolytically inhibit HBV replication in infected hepatocytes and lead to viral clearance. The possible mechanisms for this inhibition and clearance include suppressing the assembly of the pregenomic RNA-containing capsids or accelerating their degradation, preventing the formation of the replication-competent $\mathrm{HBV}$ capsid and promoting proteasome-dependent HBV degradation. ${ }^{19-21}$ However, the cytolytic anti-HBV function is achieved by the cytotoxicity of CD8 T cells. Furthermore, the data from experiments in HBV Tg mice have indicated that the noncytolytic and cytolytic antiviral actions of CD8 $\mathrm{T}$ cells are not only independent of each other but also occur in an asynchronous and oscillatory manner. ${ }^{7,22}$ After the acute phase of resolving the HBV infection, some of the HBV-specific CD8 T cells differentiate into memory CD8 T cells with increased expression of CD127, which prevent future HBV reinfection. ${ }^{23}$ However, in chronic HBV infection, which is the most common infectious state of this virus, the HBV-specific CD8 T cells are highly exhausted, displaying functional inhibition and even apoptosis. ${ }^{24}$

Possible factors for CD8 T-cell immune tolerance to $H B V$. On the basis of the functional changes in the CD4 and CD8 T cells during chronic HBV infection, it is logical to assume that restoring the functions of CD8 $\mathrm{T}$ cells from the tolerant or exhausted state may lead to the clearance of chronic HBV or $\mathrm{HCV}$ infection. Many studies have focused on the causes of tolerance in CD8 $\mathrm{T}$ cells in $\mathrm{HBV}$ infection. Studies on $\mathrm{HBc} /$ HBeAg Tg mice crossed with T-cell receptor (TCR) Tg mice, which express the receptors for the $\mathrm{HBc} / \mathrm{HBeAgs}$, have found that the HBV components induce specific immune tolerance through clonal deletion, clonal ignorance and clonal anergy. ${ }^{25}$ The exhausted HBV-specific CD8 $\mathrm{T}$ cells from chronic hepatitis $\mathrm{B}(\mathrm{CHB})$ can be functionally improved when the HBV loads are markedly reduced through treatment with viral suppressors such as Lamivudine. ${ }^{26,27}$

It has also been reported that there are more $\mathrm{CD} 11 \mathrm{~b}^{+} \mathrm{Gr}-1^{+}$ myeloid-derived suppressor cells (MDSCs) in the livers from patients with $\mathrm{CHB}$. It is possible that the suppressive role of MDSCs on T cells may contribute to the dysfunction of HBVspecific CD8 T cells. $\gamma \delta-\mathrm{T}$ cells may promote CD8 T-cell exhaustion by recruiting the MDSCs to aggregate in the liver. $^{28,29}$ Programmed death-1 (PD-1) has been found to be highly expressed on the exhausted HBV-specific CD8 T cells from patients with $\mathrm{CHB}$. Its expression is much stronger on the intrahepatic $\mathrm{T}$ cells than their peripheral counterparts and is one of the contributing factors to T-cell hypofunction because PD-1 inhibition restores T-cell effector functions, including proliferation, IFN- $\gamma$ secretion and cytolytic activity. ${ }^{24,30-33}$ This PD-1-mediated HBV-specific CD8 T-cell exhaustion can also be rescued by CD40-induced myeloid DCs. ${ }^{10} \mathrm{PD}-1$ and the signaling lymphocyte activation molecule-related receptor (CD244) are highly co-expressed on HBV-specific CD8 $\mathrm{T}$ cells, but transmit their signals independently. CD244 inhibition with antibodies against either CD244 or its ligand CD48 restores the proliferation and cytotoxicity of the exhausted CD8 T cells. ${ }^{31}$

A higher percentage of $\mathrm{HBV}$-specific CD8 $\mathrm{T}$ cells from patients with $\mathrm{CHB}$ express $\mathrm{T}$-cell immunoglobulin (Ig) and mucin-domain-containing molecule-3 (Tim-3). These T cells produce abnormal levels of IFN- $\gamma$ and TNF- $\alpha$. Moreover, these patients have a higher concentration of galectin-9 (Gal-9), the ligand of Tim-3, in the sera and on the Kupffer cells in liver, thereby suggesting that their $\mathrm{T}$ cells are prone to Gal-9triggered apoptosis and that the Kupffer cells might have a role in inducing immune tolerance, despite their classical role as APCs. Blocking Tim-3 with a recombinant Tim-3-Fc chimera revives the $\mathrm{HBV}$-specific $\mathrm{CD} 8 \mathrm{~T}$-cell functions ex vivo. ${ }^{34}$ Instead of binding to Gal-9, the HBV-specific Tim $-3^{+}$CD8 $\mathrm{T}$ cells can also bind high-mobility group box 1 and act as virus-specific Treg cells, thereby downregulating the immune reaction against $\mathrm{HBV} .{ }^{35}$ Other inhibitory receptors on the HBV-specific CD8 $\mathrm{T}$ cells that might contribute to the exhaustion of $\mathrm{T}$ cells include B-cell lymphoma-2-interacting mediator (Bim) and cytotoxic T-lymphocyte antigen-4 (CTLA-4). Both may be co-expressed and have been reported to be upregulated on the CD8 T cells from patients with $\mathrm{CHB}$. Therefore, inhibition of Bim and CTLA- 4 also results in the recovery of T-cell functions. ${ }^{36,37}$

\section{T-cell responses in $\mathrm{HCV}$ infection}

CD4 $T$ cells in $\mathrm{HCV}$ infection. The participation of CD4 $\mathrm{T}$ cells in adaptive immunity against HCV varies during the acute and chronic phases of infection, which are associated with the initiation, recovery or persistence of the infection.

In acute resolving $\mathrm{HCV}$ infection, there are more $\mathrm{HCV}$ specific CD4 $\mathrm{T}$ cells, with higher immune activity. ${ }^{38,39}$ Among the cytokines secreted from the CD4 Th1 cells, IL-2 is vital for CD4 and CD8 T-cell activation. The function of the CD8 
$\mathrm{T}$ cells decreases markedly, with respect to IFN- $\gamma$ production and proliferation, when the $\mathrm{CD} 4 \mathrm{~T}$ cells lose their ability to produce IL-2 during the chronic stage of HCV infection. Although HCV-specific CD8 T cells have the capability to proliferate, exhibit cytotoxicity and secrete IFN- $\gamma$, they are not sufficient to clear the HCV. Priming from HCV-specific CD4 $\mathrm{T}$ cells and the presence of IL-2 are critical in determining the outcome of the infection. ${ }^{40,41} \mathrm{CD} 4 \mathrm{Th} 17$ cells secrete IL-17 and IL-21. Patients with higher plasma concentrations of IL-17A and IL-21 in the acute phase are predisposed to a self-limited infection. They also have more CD4 T cells that secrete IL-21 than do patients with a chronically evolving HCV infection. Kared et al. ${ }^{42}$ has shown that the IL-21 from the CD4 T cells promotes the expansion of $\mathrm{HCV}$-specific CD8 $\mathrm{T}$ cells and prevents their Gal-9-induced apoptosis in vitro, even though they express inhibitory receptors (Tim-3). In addition, in acute resolving hepatitis $\mathrm{C}$, the $\mathrm{CD} 4 \mathrm{~T}$ cells contribute to the maturation of memory $\mathrm{CD} 8 \mathrm{~T}$ cells, which prevent reinfection with $\mathrm{HCV}^{43}$ When the $\mathrm{CD} 4 \mathrm{~T}$ cells in HCV-immunized chimpanzees are depleted, HCV reinfection results in incomplete control of the viral replication, persistent viremia and viral mutations that escape the adaptive immune system, even though the CD8 T cells in liver respond with normal function. ${ }^{39}$

In contrast, the CD4 $\mathrm{T}$ cells in chronically evolving hepatitis $\mathrm{C}$ exhibit different phenotypes, a high-level expression of inhibitory receptors (Tim-3, PD-1 and CTLA-4) accompanied by a decreased frequency of IL-21-secreting CD4 T cells ${ }^{42,44}$ and an increased number of $\mathrm{CD} 4^{+} \mathrm{CD} 25^{+} \mathrm{Foxp}^{+}$Treg cells, which then directly suppress the $\mathrm{HCV}$-specific CD8 T cells in vitro. ${ }^{45,46}$ Moreover, these cells perform their immunosuppressive functions by altering the innate immune system. ${ }^{47}$

CD8 T cells in HCV infection. By producing cytokines (mainly IFN- $\gamma$ ) and inducing cytotoxicity as their major antiviral mechanisms, CD8 T cells are responsible for the hepatic lesions in HCV, as well as the viral cytopathic effects. Thus, serum hepatic enzyme levels change synchronously with the frequency of the HCV-specific CD8 T cells but not with the HCV viral load. ${ }^{48} \mathrm{HCV}$-specific CD8 $\mathrm{T}$ cells have a fundamental role in long-term protection against $\mathrm{HCV}$. Although $\mathrm{HCV}$-immunized chimpanzees produced $\mathrm{HCV}$-specific $\mathrm{CD} 4 \mathrm{~T}$ cells, the depletion of CD8 T cells reduces the suppression of $\mathrm{HCV}$ replication. ${ }^{49}$ Unfortunately, extensive data have also indicated that the $\mathrm{HCV}$-specific CD8 T cells are impaired or exhausted in chronic $\mathrm{HCV}$ infections. It has also been noted that the number of intrahepatic and cycling $\mathrm{HCV}$-specific CD8 $\mathrm{T}$ cells does not decrease in the chronic phase, and their capacity for proliferation, IFN- $\gamma$ secretion and cytotoxicity are all significantly impaired, thus limiting their efficacy in HCV clearance. ${ }^{50-52}$

Possible factors for CD8 T-cell tolerance to HCV. Given that the immune tolerance of CD8 $\mathrm{T}$ cells is one of the major causes of chronic HCV infection, it is necessary to discern the possible factors that regulate tolerance. A variety of inhibitory mechanisms are known to be associated with the immune tolerance of the HCV-specific CD8 T cells in chronic HCV infection. First,
$\mathrm{HCV}$ itself is likely to impair the function of these $\mathrm{T}$ cells. When HCV is efficiently suppressed by HCV inhibitors, the frequency and proliferation of HCV-specific CD8 T cells is markedly increased, but this increase does not appear in those who did not respond to the same treatment. ${ }^{53}$ In addition, after repeat immunization of chimpanzees with a low dose of HCV, reinfection with $\mathrm{HCV}$ reduces IFN- $\gamma$ secretion from the HCVspecific CD8 $\mathrm{T}$ cells in the liver. ${ }^{38}$ These studies have demonstrated that the HCV load itself can affect the function of the HCV-specific CD8 T cells. Second, aside from the suppressive modulation from the $\mathrm{CD}^{+}$Tregs mentioned above, ${ }^{45,46}$ the $\mathrm{HBV}$-specific $\mathrm{CD}^{+}$Tregs also exhibit an inhibitory effect on the CD8 T cells by secreting the suppressive cytokine IL-10. ${ }^{54}$ Third, the HCV-specific CD8 T cells in liver and blood express PD-1 during both the acute and chronic phases of HCV infection; this expression disappears in the recovery phase, but remains at high levels in persistent infections. In the chronic stage, PD-1 expression is associated with impaired function of HCV-specific CD8 T cells, and PD-1 inhibition reactivates $\mathrm{CD} 8 \mathrm{~T}$-cell functions in vitro, including proliferation, IFN- $\gamma$ production and cytotoxicity, which are responsible for HCV inhibition and clearance. ${ }^{55-58}$ Fourth, the expression level of another inhibitory receptor, Tim-3, on the HCV-specific CD8 $\mathrm{T}$ cells is correlated with CD8 T-cell exhaustion and blocks the interaction between Tim-3 and Gal-9, thus restoring the CD8 T cells' immune functions. ${ }^{42,59,60}$ Finally, it has been reported that the inhibitory receptor CTLA-4 is preferentially upregulated in PD- $1^{+} \mathrm{T}$ cells in the livers of chronically HCV-infected patients, which also contributes to $\mathrm{HCV}$-specific $\mathrm{T}$-cell exhaustion. Inhibitors that block both the CTLA-4 and PD-1 inhibitory receptors exhibit a synergistic effect against chronic HCV infection by reactivating the HCV-specific CD8 T cells. ${ }^{61}$

In addition to inducing immune tolerance, $\mathrm{HCV}$ can escape adaptive immunity through mutations, ${ }^{62}$ which mainly accounts for the failure to produce an $\mathrm{HCV}$ vaccine.

Together, these findings indicate that cellular immunity, particularly the adaptive immunity mediated by CD8 T cells, has a critical role in the inhibition and clearance of HBV and HCV. This adaptive immunity results in inflammatory damage to hepatocytes. CD8 T-cell immune tolerance to the virus might be beneficial for preventing hepatic injury but would be conducive to persistent infections, which could increase the risk of hepatic cirrhosis and hepatic cancer after prolonged chronic infection. Therefore, therapeutic interventions designed to disrupt T-cell immune tolerance to HBV or HCV may be a double-edged sword in terms of their effects on the immunopathogenesis of these chronic infections. Figure 1 illustrates the functional changes in the CD8 $\mathrm{T}$ cells and their effects on chronic HBV or HCV infections (Figure 1). Although it is still unclear whether immune tolerance is caused by viral factors to promote their survival or by host factors to limit the hepatic lesions, previous studies have identified potential targets that disrupt the immune tolerance and restore the immune function of exhausted virus-specific CD8 T cells, such as blocking the inhibitory receptors on $\mathrm{T}$ cells and reducing the HBV/HCV 


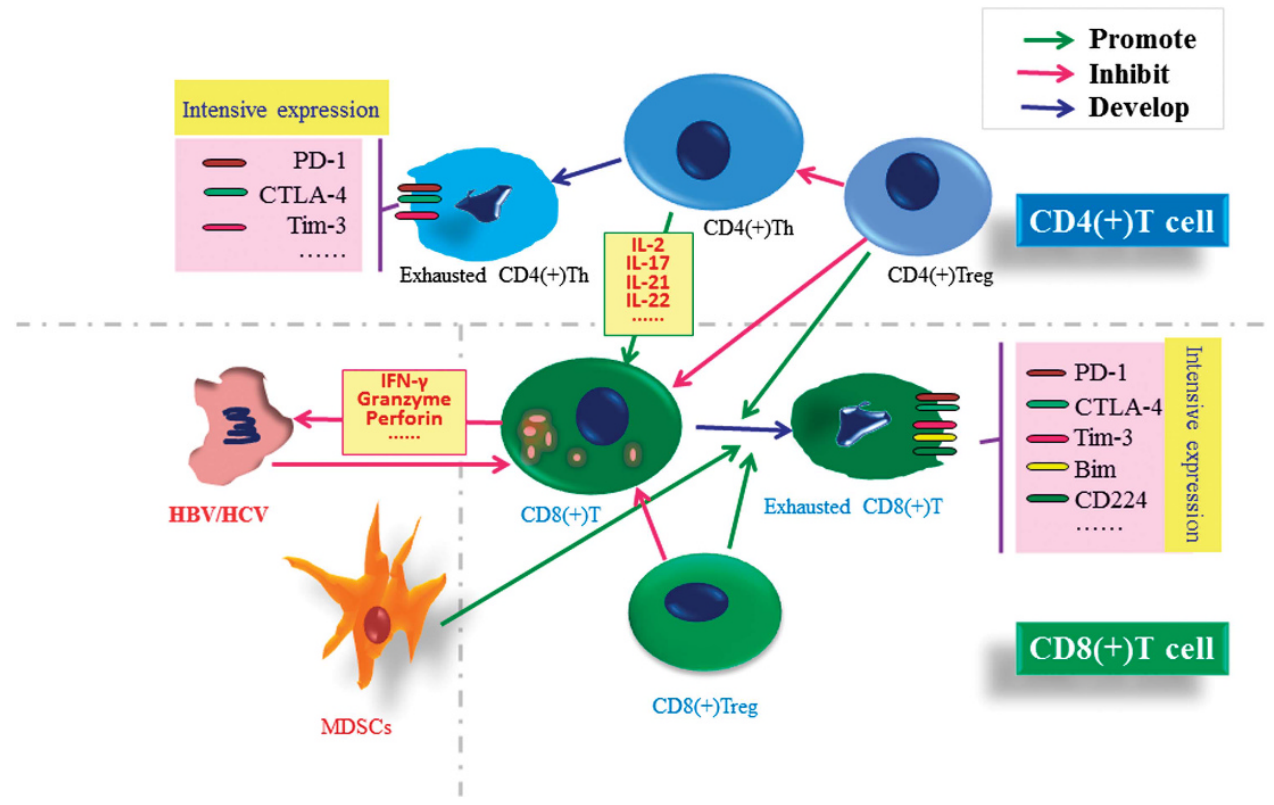

Figure 1 A schematic diagram of the functional changes and some of the influential factors in chronic HBV/HCV infections. The ability of CD8 T cells (Tc) to clear HBV/HCV is inhibited by various factors. HBV and HCV are inhibited by the virus-specific Tc. Both CD4 Treg and CD8 Treg cells suppress Tc function and promote the switch of the Tc cells from the active state in acute phase to the exhausted state in the chronic phase. CD4 Th cells are indispensable for the activation and maintenance of Tc immunity against HBV/HCV. However, Th cells can also be suppressed and exhausted similarly to Tc cells. MDSCs are another factor that facilitates Tc exhaustion. Increased expression of inhibitory protein receptors (such as PD-1, CTLA-4, Tim-3, Bim and CD224) on Tc/Th cells contributes to their exhaustion. Therefore, treatments that block the interaction between these receptors and their ligands, and inhibit Treg functions are potential therapeutic strategies for chronic HBV/HCV infections.

viral loads with various drugs. Inhibiting the Treg cells could also be a potential therapeutic strategy for chronic HBV or HCV infections.

\section{ADAPTIVE IMMUNITY TO HCC}

HCC is the most common primary malignant tumor in the liver and the fifth-most common neoplasm worldwide, representing the third-most common cancer-related death. Many cases of HCC occur in subjects with a history of chronic liver diseases, such as HBV or HCV infection, PBC and hepatic cirrhosis. At least two possible mechanisms-immunosuppression due to viral infection and viral gene integration-account for the close association between viral infection and HCC. ${ }^{63-65}$ The occurrence and prognosis of HCC are closely related to immunity, particularly T-cell-mediated adaptive immunity. Studies on lymphocytes in livers from patients with HCC have demonstrated reduced lymphocyte infiltration, which is a significant, independent predictor for relapse. These lymphocytes display different phenotypes and functions when located in the intratumoral and peritumoral regions. ${ }^{66,67}$ Because most HCC patients cannot tolerate the toxicity of traditional chemical anticarcinogens, immunotherapy is an alternative approach.

\section{CD8 $\mathrm{T}$ cells in HCC}

It is generally accepted that CD8 T cells are the fundamental adaptive immunocytes that monitor and kill tumor cells via histocompatibility leukocyte antigen class I molecule (HLA-I) limitation on the tumor cells. Over the past two decades, several HCC tumor-associated antigen (TAA)-specific CD8 $\mathrm{T}$ cells have been identified. Alpha-fetoprotein (AFP) is the most common TAA in HCC. Its epitopes are recognized by specific CD8 T cells and are broadly distributed on the AFP polypeptide, suggesting a strong and broad immunogenicity of this TAA. ${ }^{68}$ It has been reported that AFP converts DCs into tolerogenic DCs, which subsequently inhibit the induction of tumor-specific CD8 $\mathrm{T}$ cells and suppress their cytotoxic activity. ${ }^{69}$ Other TAAs that are recognized by specific CD8 $\mathrm{T}$ cells in HCC include telomerase reverse transcriptase, ${ }^{70}$ the targeting protein for Xklp-2, ${ }^{71}$ glypican-3 (GPC3), ${ }^{72}$ NY-ESO- $1,{ }^{73}$ melanoma antigen gene-A and SSX-2. ${ }^{74}$ These TAAs are detected in other cancers but are often overexpressed in HCC cells, with some of them contributing to the growth and metastasis of HCC. ${ }^{72,73}$ However, TAA-specific CD8 $\mathrm{T}$ cells lose their ability to effectively suppress or kill malignant hepatic cells in individuals with HCC. Notably, accumulating evidence indicates that suppressive $\mathrm{CD}^{+}$Tregs also increase in HCC. These tumor-infiltrating $\mathrm{CD}^{+} \mathrm{FoxP}^{+}$Tregs may contribute to HCC immune evasion and disease progression. ${ }^{75}$

\section{Possible factors affecting CD8 T-cell immunity in HCC}

There is no doubt that the identification of the causes of the immune tolerance is of critical importance in developing immunotherapies for HCC, which are aimed at improving CD8 T-cell function. Previous studies have demonstrated that 
there are multifaceted underlying causes for the CD8 T-cell functional suppression.

CD4 $T$ cells in HCC. CD4 Th cells are essential for the CD8 $\mathrm{T}$-cell response, but Th cells are reduced in HCC. TAA-specific CD4 Th cells are detected in early stages of HCC but are exhausted in advanced HCC, although they are still detected in the circulation and in hepatic tumors at lower frequencies. ${ }^{76,77}$ The exhausted CD4 Th cells may be reactivated to produce IFN- $\gamma$ if their inhibitors are removed. ${ }^{78}$

Among the $\mathrm{CD} 4 \mathrm{~T}$-cell subsets in $\mathrm{HCC}, \mathrm{CD} 4^{+} \mathrm{CD} 25^{+} \mathrm{Foxp}^{+}$ Treg cells have the most important immunoregulatory role. Marked infiltration of Treg cells has been observed in the livers from patients with HCC, and the number of intratumor Treg cells is increased compared with the peritumor regions and periphery. They are also associated with tumor vascular invasion. However, the number of CD8 T cells in the liver decreases as the number of infiltrating Treg cells increases. Their proliferation and perforin production are also suppressed by the autologous Treg cells isolated from patients with HCC. ${ }^{66,79,80}$ These isolated Treg cells effectively suppress the proliferation and cytokine secretion of $\mathrm{CD} 4^{+} \mathrm{CD} 25^{-} \mathrm{T}$ cells. ${ }^{80}$ Moreover, when the number of Treg cells from patients with HCC is decreased by a low-dose cyclophosphamide treatment, the number of IFN- $\gamma$-secreting AFP-specific CD4 T cells subsequently increases. ${ }^{81}$ These studies have indicated that, in addition to the direct suppression of the CD8 $\mathrm{T}$ cells, the $\mathrm{CD} 4^{+}$ $\mathrm{CD} 25^{+} \mathrm{Foxp}^{+}$Treg cells indirectly suppress CD8 $\mathrm{T}$ cells by inhibiting CD4 T cells. Furthermore, the secretion of inhibitory cytokines (IL-10, TGF- $\beta$ and so on) is one of the major immunosuppressive mechanisms of Treg cells. ${ }^{82} \mathrm{~A}$ recent report has indicated that TGF- $\beta$ promotes Treg differentiation in an HCC mouse model, which contributes to the progression of HCC. ${ }^{83}$ This implies that Treg activation produces a positive, immunosuppressive feedback loop in HCC.

MDSCs and other factors that influence the CD8 cells in HCC. In addition to CD4 $\mathrm{T}$ cells, other factors are involved in the immune tolerance to HCC (Figure 2). It has been found that MDSC infiltration is markedly increased in HCC. Some studies have also found that the number of MDSCs is increased in the peripheral lymphatic tissue and blood, resulting in extensive suppression of both innate and adaptive immunity. ${ }^{84-86}$ MDSCs suppress natural killer cells in HCC by cell-cell contact. ${ }^{87}$ Although there is no evidence for direct MDSC-mediated suppression of TAA-specific CD8 T cells in HCC, the results from several studies have suggested that MDSCs inhibit CD8 T cells through indirect pathways. MDSCs produce inhibitory cytokines, such as IL-10, thereby suppressing CD8 T cells because HCC patients with increased numbers of MDSCs also have higher levels of IL-10. ${ }^{86}$ MDSCs also indirectly impair the functions of $\mathrm{CD} 8 \mathrm{~T}$ cells through autologous $\mathrm{CD} 4^{+} \mathrm{CD} 25^{+} \mathrm{Foxp}^{+}$Treg cells because the latter can be activated when co-cultured with MDSCs. ${ }^{88}$ In addition, the suppression of DCs by MDSCs might inhibit adaptive immunity in HCC by reducing TAA presentation on the DCs. ${ }^{86}$

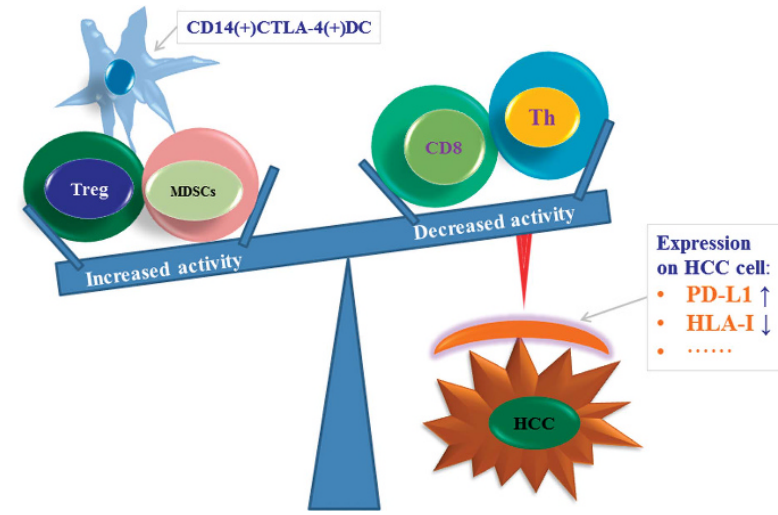

Figure 2 Changes in the functions of the major adaptive immune cells in HCC. CD8 T cells, the primary HCC-specific killer and its helper $\mathrm{CD} 4 \mathrm{CD}^{-} 5^{-}$Th cells are inhibited, whereas the inhibitory immune cells, including Treg cells, MDSCs and CD $14^{+} \mathrm{CTLA}-4^{+}$ DCs, are increased in HCC patients. Moreover, the HCC cell itself can evade adaptive immune surveillance through several strategies, such as reduced expression of the HLA-I antigen and enhanced expression of PD-L1, the ligand of PD-1, which is expressed on the tumor-filtrating $T$ cells and mediates T-cell suppression or apoptosis. These functional alterations of the T cells promote HCC occurrence and development.

Recently, CD $14^{+}$CTLA $-4^{+}$DCs have been detected in patients with HCC. These DCs are thought to be a new subset of DCs because they secrete the immunosuppressive cytokine IL-10 and indoleamine-2, 3-dioxygenase, which are dependent on CTLA-4 expression. The in vitro suppressive effect of DCs on CD4 T cells has also been experimentally verified. ${ }^{89}$ These regulatory DCs inhibit CD8 T cells via both immunosuppressive cytokines and downregulation of CD4 T cells.

As discussed above in the section on adaptive immunity to viral infection, PD-1 is a well-known immunosuppressive receptor on $\mathrm{T}$ cells. It has been shown that $\mathrm{PD}-1$ is highly expressed on $\mathrm{T}$ cells that are infiltrating the hepatic tumor and in the circulation, whereas PD-L1, the ligand of PD-1, is overexpressed on hepatic tumor cells. ${ }^{90-94}$ In vitro, the IFN- $\gamma$ secreted by CD8 $\mathrm{T}$ cells with increased PD-1 expression induces high levels of PD-L1 expression on cancer cells, ${ }^{91,92}$ which may lead to exhaustion of the TAA-specific CD8 T cells in the tumor through a vicious feedback loop and subsequent tumor cell immune escape. Thus, the increased PD-L1 expression on HCC cells might have valid prognostic value in that its expression levels are inversely related to HCC prognosis. ${ }^{93,95}$

For HCC developed from HBV/HCV infection, all of the aforementioned immunosuppressive mechanisms related to the viral infections might also contribute to the immunosuppression in HCC. To escape from the host's immune surveillance, HCC cells adopt various mechanisms, including reduced HLAI antigen expression to elude CD8 T-cell attack ${ }^{95,96}$ and enhanced PD-L1 expression to inhibit CD8 T cells with high levels of PD-1 expression. ${ }^{91}$ Unfortunately, the underlying escape mechanism remains unclear, which could account for the poor efficacy of most immunotherapies currently available for HCC, even though these immune interventions have been 
validated in ex vivo experiments. Additional studies on HCC adaptive immunity are necessary.

\section{ADAPTIVE IMMUNITY IN AILDS}

AILDs are mainly composed of $\mathrm{PBC}$, primary sclerosing cholangitis and $\mathrm{AIH}$, among which $\mathrm{PBC}$ and $\mathrm{AIH}$ will be the focus of this review. Unlike viral hepatitis and HCC, in which the adaptive immune system targets the virus-infected cells and cancer cells, the adaptive immune system targets normal hepatic parenchymal cells (biliary ductule cells and hepatocytes) in AILDs, although most patients with chronic viral hepatitis infections and AILDs eventually present hepatic cirrhosis and even liver cancer.

\section{Adaptive immunity in PBC}

$\mathrm{PBC}$ is one of the most common autoimmune hepatic diseases. Although they vary among regions and races, $\mathrm{PBC}$ prevalence and incidence have increased in recent decades. ${ }^{97,98} \mathrm{PBC}$ is a typical organ-specific autoimmune disease, in which the biliary ductule is the major target of destruction. Patients with PBC suffer from symptoms ranging from lymphocytic cholangitis to progressive ductopenia, which are associated with cholestasis and biliary fibrosis. ${ }^{99,100}$ Recent studies in patients and animal models have demonstrated that the interplay of genetics and the environment with the innate and adaptive immune systems is highly orchestrated in the pathogenesis of PBC. ${ }^{101-113}$ The presence of antimitochondrial antibodies (AMA), particularly the autoantibody against pyruvate decarboxylase E2 (PDC-E2), is the serological hallmark of $\mathrm{PBC}$ and has a potential pathogenic role. ${ }^{14-116}$ However, liver-infiltrating autoreactive $\mathrm{T}$ lymphocytes also have crucial roles in the destruction of the small bile ducts.

CD8 $T$ cells in PBC. Among the T-cell subsets, CD8 T cells have a decisive role in the immunopathogenesis of PBC. In PBC patients, CD8 $\mathrm{T}$ cells abundantly infiltrate the hepatic portal regions. Whereas PDC-E2-specific CD8 $\mathrm{T}$ cells are detected in the peripheral blood at early stages of $\mathrm{PBC}$, their frequency in the liver-infiltrating lymphocytes is 10 times higher than that in the blood. ${ }^{117,118}$ In experimental mouse models of PBC, the liver lesions are accompanied by extensive CD8 T-cell infiltration in the portal region, granuloma and even fibrosis. ${ }^{119-124}$ In addition, these animals exhibit increased serum levels of AMA, TNF- $\alpha$ and IFN- $\gamma$. Importantly, the significance of the CD8 $\mathrm{T}$ cells in $\mathrm{PBC}$ is illustrated by the induction of $\mathrm{PBC}$ with adoptive transfer of $\mathrm{CD} 8 \mathrm{~T}$ cells, but not CD4 T cells, from the dnTGF- $\beta$ RII mouse model of PBC to recipient C57BL/6J mice. ${ }^{122,125}$ Furthermore, instead of the extrinsic factors around the CD8 T-cell environment, the intrinsic deficiency (abnormal TGF- $\beta$ RII signaling) in CD8 $\mathrm{T}$ cells per se determines that the cholangiocytes are the target of the transferred CD8 T cells. ${ }^{126}$ This crucial role of CD8 $\mathrm{T}$ cells partially explains the pathogenesis in AMA-negative PBC patients.

CD4 T cells in PBC. The autoimmune pathogenesis in $\mathrm{PBC}$ is also orchestrated by different subsets of $\mathrm{CD} 4 \mathrm{~T}$ cells.
Infiltration of $\mathrm{CD} 4 \mathrm{~T}$ cells, including major histocompatibility complex class II-restricted PDC-E2-specific CD4 T cells, is evident in the inflammatory portal area in the livers from PBC patients or animal models. ${ }^{123,127-129}$ PDC-E2-specific CD4 $\mathrm{T}$ cells have also been observed in AMA-negative $\mathrm{PBC}$ patients. ${ }^{129}$ In $\mathrm{PBC}$ patients and mouse models of $\mathrm{PBC}$, increased numbers of CD4 T cells (Th17) have been observed within the portal tracts compared with the periphery. ${ }^{130}$ An analysis of IL-12/Th1 and IL-23/Th17 biliary microenvironment has suggested that the Th17 cells have a dominant role in the perpetuation of $\mathrm{PBC}$ immunopathology mediated by the Th1 cells at early stage. ${ }^{131}$

The T-cell populations, including Treg cells and Tfh cells, have also recently been examined in PBC. Unlike the Treg cells in HCC, those in PBC display a decreased immunosuppressive function. The frequency of $\mathrm{CD} 4^{+} \mathrm{CD} 25^{+} \mathrm{Foxp}^{+}$Treg cells is reduced in the blood and inflammatory portal tracts of patients with PBC. The ratio of CD8 $\mathrm{T}$ cells/Treg cells increases with disease progression. ${ }^{132}$ Similar findings have been reported in $\mathrm{Ae}_{2}{ }^{-1-}$, foxp $3^{3^{f f / Y}} \mathrm{Sf}^{123}$ and IL-2 receptor knockout (IL-2R ${ }^{-1-}$ ) mouse models of PBC. ${ }^{125}$ Interestingly, a case report has described a subject with a classical PBC clinical manifestation (positive for the PDC-E2 antibody and PBC hepatic histopathology) due to a congenital deficiency of the alpha subunit of the IL-2 receptor. ${ }^{133}$ In the absence of Treg cells from the donor dnTGF- $\beta$ RII mice, it is difficult to induce PBC in the recipient mice solely by adoptive transfer of CD8 $\mathrm{T}$ cells. Normal, functional Treg cells (such as those from B6 mice) reduce hepatic damage in the recipient mice, which is associated with reduced T-cell cytotoxicity toward the cholangiocytes after $\mathrm{CD} 8^{+}$T-cell transfer. ${ }^{134,135}$ In fact, a recent study on Treg cells from the dnTGF- $\beta$ RII mice has confirmed that genetic defects in the TGF- $\beta$ signaling pathway are responsible for the immune dysregulation and subsequent inflammatory upregulation in the PBC mouse model. ${ }^{136}$ In another study, $\mathrm{CD} 4^{-1-}$ dnTGF- $\beta$ RII Tg mice have been generated to examine the contribution of $\mathrm{CD} 4$ cells to the autoimmune cholangitis in the dnTGF- $\beta$ RII mice. The $C D 4^{-1-}$ dnTGF- $\beta$ RII $\mathrm{Tg}$ mice produce more IFN- $\gamma$ and exhibit a more severe biliary pathology than do the dnTGF- $\beta$ RII mice. Interestingly, the liver pathology is alleviated by adding back the wild-type $\mathrm{CD}_{4}^{+}$ $\mathrm{T}$ cells, which contain Tregs, through bone marrow transplantation or parabiosis. ${ }^{137}$ These observations suggest that the Treg cells from wild-type mice modulate biliary disease by limiting the differentiation of autoantigen-specific $\mathrm{CD}^{+} \mathrm{T}$ cells. In summary, these studies have suggested that Treg cells might be a potential target of immunotherapy for PBC. However, PDCE2-specific Treg cells have yet to be identified. In patients with PBC, increased numbers of Tfh cells, which are associated with elevated levels of IL-21, have been observed in the blood, liver and spleen. However, the increased numbers of Tfh cells might decrease significantly following effective ursodeoxycholic acid treatment. ${ }^{138,139}$

Other possible factors affecting T-cell immunity in PBC. T-cell function in $\mathrm{PBC}$ is also influenced by other factors, including 
cholangiocytes and various receptors on $\mathrm{T}$ cells. In the immunopathological process of $\mathrm{PBC}$, cholangiocytes not only are the target and victim of immune reaction but also are active factors in the immune response (Figure 3). Cholangiocytes express the HLA-II antigen and act as APCs. CD80 and CD86 costimulators are expressed on cholangiocytes and interact with the CD28 receptor on T cells, resulting in T-cell activation. Cholangiocytes also facilitate innate and adaptive immunity by producing cytokines and ILs, such as IL-6, IL-8 and monocyte chemotactic protein-1 (MCP-1). ${ }^{140}$ By expressing the adhesion molecule CX3CL1 (chemokine-adhesion molecule (fractalkine)), cholangiocytes recruit CD4 and CD8 T cells that express CX3CR1 (adhesion molecule, the ligand of CX3CL1). ${ }^{141}$ CD40 on cholangiocytes induces cholangiocyte apoptosis and activates macrophages after binding to the CD40 ligand (CD40L) on macrophages. ${ }^{142}$ It is likely that the CD40L expressed on $\mathrm{T}$ cells has a similar function. Cholangiocyte-specific epitopes on immunologically intact PDC-E2 might be one of the mechanisms underlying the biliary-specific autoimmune pathogenesis in PBC. ${ }^{143}$

A study on genetic and epigenetic modifications of the CD40L gene in circulating CD4 T cells from PBC patients and healthy controls has found that the degree of DNA methylation of the CD40L promoter is lower in PBC patients than controls, which might lead to increased CD40L expression on CD4 $\mathrm{T}$ cells and promote their activity. Furthermore, this study has also demonstrated that the decrease in methylation is inversely related to the serum levels of IgM. ${ }^{144}$ Nevertheless, a preliminary study has shown that blocking CD40L with an antiCD40L antibody has limited therapeutic effects in a mouse model of PBC (dnTGF- $\beta$ RII Tg mice). ${ }^{145}$ In another study using a 2-octynoic acid-conjugated bovine serum albumin
(2OA-BSA)-immunized mouse model of PBC to examine the therapeutic effect of CTLA-4-Ig, which inhibits CTLA-4, CTLA-4-Ig has been found to prevent disease onset when administered before the 2OA-BSA immunization. Even after the appearance of liver lesions, the administration of CTLA4-Ig reduces intrahepatic T-cell infiltrates and biliary cell damage. ${ }^{146}$ These results indicate that CTLA-4-Ig might have a potential therapeutic value for PBC.

It should be noted that some patients with $\mathrm{PBC}$ have an increased risk for hepatic carcinoma or present extrahepatic malignancies and other autoimmune conditions. ${ }^{147-150}$ Tools in immunogenetics, molecular biology, immunopathology, bioinformatics and systems analysis will continue to facilitate the unveiling of the underlying adaptive immune mechanisms and the identification of the relevant clinical markers in monitoring the prognosis of $\mathrm{PBC}$, and as possible clinical interventions for the T-cell responses in $\mathrm{PBC}$. $^{151-155}$

\section{Adaptive immunity in AIH}

$\mathrm{AIH}$ is a common autoimmune chronic inflammatory liver disease characterized by the presence of multiple autoantibodies, elevated serum aminotransferase levels, excessive hepatic lymphoplasmocytic infiltration and interface hepatitis. Its prevalence varies in different geographical areas and races. In spite of the currently available effective therapeutic agents, such as corticoid and azathiopurine, AIH accounts for $10-54 \%$ of cryptogenic cirrhosis. ${ }^{156,157}$ The exact pathogenesis of $\mathrm{AIH}$ remains an enigma. However, accumulating data indicate that $\mathrm{T}$ cells have pivotal roles in the immunopathogenesis of $\mathrm{AIH}$ through immune regulation and immune effector functions, and multiple autoantibodies are also important participants. ${ }^{158,159}$

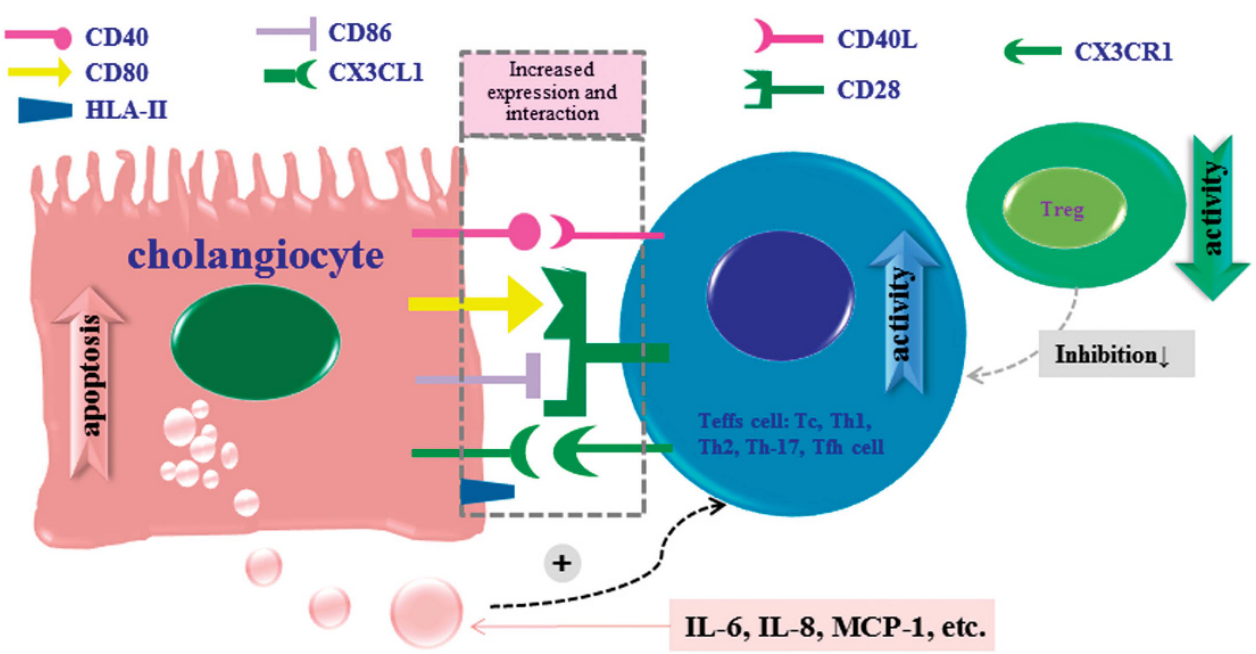

Figure 3 A schematic representation of the interaction between adaptive immunocytes and cholangiocytes in PBC. Teffs, which include Th1, Th2, Th17 and Tfh cells, are, at least in part, over-activated by downregulated Treg cells. Cholangiocytes are both the victim and accomplice of the autoimmunity in PBC. Upon aberrant expression of HLA-II, cholangiocytes can act as APCs to promote adaptive autoimmunity in the liver. The expression of CX3CL1 contributes to recruiting T cells to the liver. CD40, CD80 and CD86 expressed on cholangiocytes activate Teffs. Furthermore, the cytokines and interleukins (such as IL-6, IL-8 and MCP-1) secreted by the cholangiocytes promote autoimmunity. Collectively, these factors will increase adaptive autoimmunity and cholangiocyte apoptosis in PBC. 
CD8 $T$ cells in AIH. In AIH patients, the ratio of liver CD8/ CD4 $\mathrm{T}$ cells increases with the development of disease activity. ${ }^{160}$ A hepatic pathological study has indicated that emperipolesis is one of the characteristics of $\mathrm{AIH}$, as observed in $65.3 \%$ of livers from $\mathrm{AIH}$ patients, whereas the percentage was only $17.9,14.9$ and $25.6 \%$ in patients with PBC, HBV infections or drug-induced liver injury, respectively. This emperipolesis is predominantly mediated by CD8 T cells and is correlated with higher serum aminotransferase (alanine transarninase/aspartate aminotransferase) levels and severe necroinflammation and fibrosis in the liver. ${ }^{161}$ Evidence from animal studies has also supported the important roles of CD8 $\mathrm{T}$ cells in the pathogenesis of AIH. In AIH mouse models, CXCR3 and CCR6 are highly expressed on CD8 T cells, which facilitate their recruitment to the liver because their respective ligands, CXCL9 and CCL20, are highly expressed in inflamed liver. ${ }^{162,163}$ Adoptive transfer of total splenocytes, but not CD4 T-cell-depleted splenocytes from an AIH model (NTx-PD-1 ${ }^{-/-}$ mice), into $R A G 2^{-1-}$ recipient mice leads to massive inflammatory necrosis of the hepatic parenchyma. In contrast, the transfer of CD8 T-cell-depleted splenocytes in this AIH model alleviates hepatic damage. ${ }^{164}$ In fact, the hepatic damage caused by CD8 $\mathrm{T}$ cells in AIH is at least partially owing to the dysregulation of other related innate and adaptive immune cells.

CD4 $T$ cells and other related immunocytes in AIH. It has been found that different subsets of CD4 T cells, particularly Treg cells, exhibit notable effects in AIH. Histopathologically, the frequency of infiltrating CD4 T (Th) cells is higher than CD8 $\mathrm{T}$ cells at early stage AIH. ${ }^{160}$ The spontaneous apoptosis of CD4 T cells is markedly reduced, and their Tim-3 expression is clearly increased in AIH. ${ }^{165,166}$ Compared with those in the CHB patients and healthy controls, the frequencies of Th17 cells in both the liver and blood, and the circulating and intrahepatic levels of IL-17 are substantially elevated in AIH. This increased hepatic expression of IL-17 in AIH is associated with inflammation and fibrosis in liver. ${ }^{167}$ In an adoptive transfer experiment with an AIH mouse model, the recipient mice (RAG2 ${ }^{-1-}$ mice) have been found not to develop AIH when the CD4 $\mathrm{T}$ cells are selectively deleted from the donor splenocytes from the NTx-PD- $1^{-/-}$AIH model mice. ${ }^{164}$ This finding shows that the CD4 $\mathrm{T}$ cells promote autoimmunity in AIH mice.

Treg cells have attracted much attention over the past decade because of their immunosuppressive functions and potential therapeutic value. ${ }^{168}$ In animal experiments, neonatal PD-1-knockout mice spontaneously develop fatal AIH (mouse AIH model) when the thymus is excised to reduce the number of Treg cells. This AIH induction is suppressed by adoptive transfer of Treg cells. ${ }^{164}$ Similar models have been used in other AIH studies. ${ }^{162,163,169}$ In AIH patients, Treg cells suppress autoimmunity by direct contact with the $\mathrm{CD} 4^{+} \mathrm{CD} 25^{-} \mathrm{T}$ cells and the secretion of regulatory cytokines such as IL-4, IL-10 and TGF- $\beta .^{165}$ In addition, the Treg cells might mediate immune suppression through the expression of CD39 and
CD73. CD39 is an ectoenzyme (nucleoside triphosphate diphosphohydrolase-1, NTPDase-1) that degrades ATP to AMP. The decreased ATP levels reduce ATP-related effects, as exemplified by the $\mathrm{P} 2$ receptor-induced cytotoxicity and DC maturation. CD73 is an ecto-5'-nucleotidase that converts extracellular 5-AMP to adenosine. This adenosine might bind to the adenosine $\mathrm{A} 2 \mathrm{~A}$ receptors on activated $\mathrm{T}$ cells and exert immunosuppressive effects. Hence, the co-expression of CD39 and CD73 on Treg cells and their concerted effect are likely to be another immunosuppressive mechanism of Treg cells. ${ }^{170-172}$ The Treg cells in AIH exhibit not only reduced expression of CD39 but also reduced NTPDase-1 activity, and also a reduced ability to inhibit IL-17 secretion from Th17 cells, which might contribute to autoimmunity in $\mathrm{AIH} .{ }^{173}$ The interaction between Gal-9 on the Treg cells and Tim-3 on the Th cells might be an important mechanism for the direct contact suppression mediated by Treg cells. Another study has demonstrated that $\mathrm{AIH}$ patients exhibit reduced levels of Gal-9 and Tim-3 on the Treg cells and $\mathrm{CD} 4{ }^{+} \mathrm{CD} 25^{-}$effector cells, respectively. ${ }^{166}$ Although decreased numbers of Treg cells in $\mathrm{AIH}$ have been reported in a number of studies, ${ }^{173-175}$ other studies have recently demonstrated that the Treg cells are not impaired in AIH. ${ }^{160,176}$ These authors have found that neither the number nor the suppressive function of Treg cells in the liver and blood of AIH patients is reduced, as compared with healthy controls. The frequency of Treg cells in patients with active AIH is significantly higher than those in the remission stage. In addition, the intrahepatic ratio of Treg/Teffs (effector $\mathrm{T}$ cells) in patients who respond to treatment is higher than that in nonresponders. In in vitro experiments, Treg cells are more sensitive to the immune suppressor corticoids than $\mathrm{T}$ effective cells, which might partially explain the high relapse rates when the current immunosuppressive treatment is discontinued. ${ }^{160,176}$ The intrahepatic microenvironment, including the cytokine and chemokine profiles, also affects the numerical and functional imbalance of the Treg and Teffs in AIH patients. ${ }^{177}$ Together, these results suggest that the role of Treg cells in AIH immunopathology remains controversial.

In addition to Th and Treg cells, other immune cells are associated with adaptive cell immunity in AIH. A recent study in an AIH animal model has demonstrated that CD8 T cells are activated by IL-21 secreted by Tfh cells, which is surprising because Tfh cells are widely accepted as a special subset of CD4 $\mathrm{T}$ cells that assist with B-cell development. ${ }^{163} \gamma \delta$-T cells account for $15-25 \%$ of $\mathrm{T}$ cells in the liver. They not only act as cytotoxic $\mathrm{T}$ cells that regulate death receptor-mediated apoptosis and cytolytic degranulation but also act as immunoregulatory cells that secrete various cytokines, such as IFN- $\gamma$, IL-17, IL-4, IL-10, TGF- $\beta$ and granulocyte-macrophage colony-stimulating factor (GM-CSF). ${ }^{178}$ Indeed, the number of $\gamma \delta$-T cells in AIH patients is increased, and they secrete higher levels of IFN- $\gamma$ and granzyme B than those in healthy controls, which might contribute to the autoimmune damage in AIH. ${ }^{175}$ A recent study has demonstrated that B cells inhibit CD4 $\mathrm{T}$ cells in an AIH mouse model. This suppressive function is dependent on the expression of CD11b on B cells 
and is mediated by impairing TCR signaling transduction and promoting TCR downregulation. IL-10 is mainly secreted by CD4 $\mathrm{T}$ cells and enhances CD11b expression, thus implying that $\mathrm{CD} 4 \mathrm{~T}$ cells and $\mathrm{B}$ cells might regulate each other in AIH. ${ }^{179}$

\section{SUMMARY}

In conclusion, adaptive immunity, particularly cellular adaptive immunity, has a very important role in the immunopathology involved in the onset, development and prognosis of infection, tumor formation and autoimmunity in the liver. Adaptive immunity in the liver is mediated by numerous factors with extensive and complex interactions. In general, immunosuppression is dominant in persistent infections, such as chronic HBV or HCV infections, and hepatic tumors, such as HCC, whereas over-reactive immunity controls the pathogenesis in AILD, both of which can be ascribed to an immunoregulatory disorder. ${ }^{17,180-185}$ The current limited understanding of this disorder has restricted the development of effective interventions to correct the decreased or increased adaptive immunity. Although this review primarily focuses on the current knowledge regarding the adaptive immunity associated with several representative diseases, adaptive immunity in the liver probably counters more than infections, neoplasms and hepatic autoimmune diseases. Moreover, the innate immunity in the liver is also very important in hepatic immunopathology, which is reviewed in several other papers in this issue. Innate and adaptive immunities interact and closely regulate each other in a complex manner through the process of hepatic immunity, thus making the regulation of adaptive immunity in liver more enigmatic. With the growing knowledge of adaptive liver immunology, physicians and scientists are much better equipped to further examine the multiple facets of human liver diseases and identify more effective clinical interventions.

\section{CONFLICT OF INTEREST}

The authors declare no conflict of interest.

\section{ACKNOWLEDGEMENTS}

This work was supported in part by a grant from the National Institutes of Health, DK39588.

1 Bogdanos DP, Gao B, Gershwin ME. Liver immunology. Compr Physiol 2013; 3: 567-598.

2 Doherty DG. Immunity, tolerance and autoimmunity in the liver: a comprehensive review. J Autoimmun 2015; 66: 60-75.

3 Hudspeth K, Donadon M, Cimino M, Pontarini E, Tentorio P, Preti M et al. Human liver-resident CD56/CD16 NK cells are retained within hepatic sinusoids via the engagement of CCR 5 and CXCR6 pathways. J Autoimmun 2015; 66: 40-50.

4 Xu X, Zhang S, Jin R, Wang K, Li P, Lin L et al. Retention and tolerance of autoreactive $\mathrm{CD} 4(+)$ recent thymic emigrants in the liver. J Autoimmun 2015; 56: 87-97.

5 Zhang H, Liu Y, Bian Z, Huang S, Han X, You Z et al. The critical role of myeloid-derived suppressor cells and FXR activation in immunemediated liver injury. J Autoimmun 2014; 53: 55-66.
6 Selmi C, Podda M, Gershwin ME. Old and rising stars in the lymphoid liver. Semin Immunopathol 2009; 31: 279-282.

7 Guidotti LG, Chisari FV. Immunobiology and pathogenesis of viral hepatitis. Annu Rev Pathol 2006; 1: 23-61.

8 Sprent J, Surh CD. T cell memory. Annu Rev Immunol 2002; 20: 551-579.

9 Bertolino P, Bowen DG, McCaughan GW, Fazekas de St Groth B. Antigen-specific primary activation of CD8+ $T$ cells within the liver. $\mathrm{J}$ Immunol 2001; 166: 5430-5438.

10 Isogawa M, Chung J, Murata Y, Kakimi K, Chisari FV. CD40 activation rescues antiviral CD8(+) T cells from PD-1-mediated exhaustion. PLoS Pathog 2013; 9: e1003490.

11 Thomson AW, Knolle PA. Antigen-presenting cell function in the tolerogenic liver environment. Nat Rev Immunol 2010; 10: 753-766.

12 Crispe IN. Liver antigen-presenting cells. J Hepatol 2011; 54: 357-365.

13 lannacone M, Sitia G, Ruggeri ZM, Guidotti LG. HBV pathogenesis in animal models: recent advances on the role of platelets. J Hepatol 2007; 46: 719-726.

14 Zhang JY, Zhang Z, Lin F, Zou ZS, Xu RN, Jin L et al. Interleukin-17producing $\mathrm{CD} 4(+) \mathrm{T}$ cells increase with severity of liver damage in patients with chronic hepatitis B. Hepatology 2010; 51: 81-91.

15 Zhang Y, Cobleigh MA, Lian JQ, Huang CX, Booth CJ, Bai XF et al. A proinflammatory role for interleukin-22 in the immune response to hepatitis B virus. Gastroenterology 2011; 141: 1897-1906.

$16 \mathrm{Xu}$ D, Fu J, Jin L, Zhang H, Zhou C, Zou Z et al. Circulating and liver resident $C D 4+C D 25+$ regulatory $T$ cells actively influence the antiviral immune response and disease progression in patients with hepatitis B. J Immunol 2006; 177: 739-747.

17 Shen C, Yan WZ, Zhao CY, Che HH, Liu XY, Liu ZZ et al. Increased $\mathrm{CD} 4+\mathrm{CD} 25+$ regulatory $\mathrm{T}$ cells correlate with poor short-term outcomes in hepatitis B virus-related acute-on-chronic liver failure patients. J Microbiol Immunol Infect 2015; 48: 137-146.

18 Thimme R, Wieland S, Steiger C, Ghrayeb J, Reimann KA, Purcell RH et al. CD8(+) T cells mediate viral clearance and disease pathogenesis during acute hepatitis B virus infection. J Virol 2003; 77: 68-76.

19 Wieland SF, Eustaquio A, Whitten-Bauer C, Boyd B, Chisari FV. Interferon prevents formation of replication-competent hepatitis $B$ virus RNA-containing nucleocapsids. Proc Natl Acad Sci USA 2005; 102: 9913-9917.

20 Robek MD, Wieland SF, Chisari FV. Inhibition of hepatitis B virus replication by interferon requires proteasome activity. J Virol 2002; 76: 3570-3574.

21 Wieland SF, Guidotti LG, Chisari FV. Intrahepatic induction of alpha/ beta interferon eliminates viral RNA-containing capsids in hepatitis B virus transgenic mice. J Virol 2000; 74: 4165-4173.

22 Isogawa M, Furuichi Y, Chisari FV. Oscillating CD8(+) T cell effector functions after antigen recognition in the liver. Immunity 2005; 23: 53-63.

23 Boettler T, Panther E, Bengsch B, Nazarova N, Spangenberg HC, Blum $\mathrm{HE}$ et al. Expression of the interleukin-7 receptor alpha chain (CD127) on virus-specific CD8+ T cells identifies functionally and phenotypically defined memory $T$ cells during acute resolving hepatitis B virus infection. J Virol 2006; 80: 3532-3540.

24 Boni C, Fisicaro P, Valdatta C, Amadei B, Di Vincenzo P, Giuberti T et al. Characterization of hepatitis B virus (HBV)-specific T-cell dysfunction in chronic HBV infection. J Virol 2007; 81: 4215-4225.

25 Chen M, Sallberg M, Hughes J, Jones J, Guidotti LG, Chisari FV et al. Immune tolerance split between hepatitis $B$ virus precore and core proteins. J Virol 2005; 79: 3016-3027.

26 Boni C, Laccabue D, Lampertico $P$, Giuberti T, Vigano M, Schivazappa S et al. Restored function of HBV-specific T cells after long-term effective therapy with nucleos(t)ide analogues. Gastroenterology 2012; 143: 963-973.

27 Boni C, Penna A, Ogg GS, Bertoletti A, Pilli M, Cavallo C et al. Lamivudine treatment can overcome cytotoxic T-cell hyporesponsiveness in chronic hepatitis B: new perspectives for immune therapy. Hepatology 2001; 33: 963-971.

28 Kong X, Sun R, Chen Y, Wei H, Tian Z. gammadeltaT cells drive myeloid-derived suppressor cell-mediated $\mathrm{CD} 8+\mathrm{T}$ cell exhaustion in hepatitis B virus-induced immunotolerance. In J Immunol 2014, 1645-1653. 
29 Chen S, Akbar SM, Abe M, Hiasa Y, Onji M. Immunosuppressive functions of hepatic myeloid-derived suppressor cells of normal mice and in a murine model of chronic hepatitis B virus. Clin Exp Immunol 2011; 166: 134-142.

30 Fisicaro P, Valdatta C, Massari M, Loggi E, Ravanetti L, Urbani S et al. Combined blockade of programmed death-1 and activation of CD137 increase responses of human liver T cells against HBV, but not HCV. Gastroenterology 2012; 143: 1576-1585.

31 Raziorrouh B, Schraut W, Gerlach T, Nowack D, Gruner NH, Ulsenheimer A et al. The immunoregulatory role of CD244 in chronic hepatitis $B$ infection and its inhibitory potential on virus-specific CD8 + T-cell function. Hepatology 2010; 52: 1934-1947.

32 Fisicaro $P$, Valdatta C, Massari M, Loggi E, Biasini E, Sacchelli L et al. Antiviral intrahepatic T-cell responses can be restored by blocking programmed death-1 pathway in chronic hepatitis B. Gastroenterology 2010; 138: 682-693.

33 Bengsch B, Martin B, Thimme R. Restoration of HBV-specific CD8+ $T$ cell function by PD-1 blockade in inactive carrier patients is linked to T cell differentiation. J Hepatol 2014; 61: 1212-1219.

34 Nebbia G, Peppa D, Schurich A, Khanna P, Singh HD, Cheng Y et al. Upregulation of the Tim-3/galectin-9 pathway of T cell exhaustion in chronic hepatitis B virus infection. PLoS One 2012; 7: e47648.

35 Dolina JS, Braciale TJ, Hahn YS. Liver-primed CD8+ T cells suppress antiviral adaptive immunity through galectin-9-independent T-cell immunoglobulin and mucin 3 engagement of high-mobility group box 1 in mice. Hepatology 2014; 59: 1351-1365.

36 Lopes AR, Kellam P, Das A, Dunn C, Kwan A, Turner J et al. Bim-mediated deletion of antigen-specific CD8 T cells in patients unable to control HBV infection. J Clin Invest 2008; 118: 1835-1845.

37 Schurich A, Khanna P, Lopes AR, Han KJ, Peppa D, Micco L et al. Role of the coinhibitory receptor cytotoxic T lymphocyte antigen- 4 on apoptosis-Prone CD8 T cells in persistent hepatitis B virus infection. Hepatology 2011; 53: 1494-1503.

38 Park SH, Veerapu NS, Shin EC, Biancotto A, McCoy JP, Capone S et al. Subinfectious hepatitis $C$ virus exposures suppress $T$ cell responses against subsequent acute infection. Nat Med 2013; 19 : 1638-1642.

39 Grakoui A, Shoukry NH, Woollard DJ, Han JH, Hanson HL, Ghrayeb J et al. HCV persistence and immune evasion in the absence of memory T cell help. Science 2003; 302: 659-662.

40 Smyk-Pearson S, Tester IA, Klarquist J, Palmer BE, Pawlotsky JM, Golden-Mason $\mathrm{L}$ et al. Spontaneous recovery in acute human hepatitis $C$ virus infection: functional T-cell thresholds and relative importance of CD4 help. J Virol 2008; 82: 1827-1837.

41 Semmo N, Day CL, Ward SM, Lucas M, Harcourt G, Loughry A et al. Preferential loss of IL-2-secreting CD4+ T helper cells in chronic HCV infection. Hepatology 2005; 41: 1019-1028.

42 Kared H, Fabre T, Bedard N, Bruneau J, Shoukry NH. Galectin-9 and IL-21 mediate cross-regulation between Th17 and Treg cells during acute hepatitis C. PLoS Pathog 2013; 9: e1003422.

43 Urbani S, Amadei B, Fisicaro P, Tola D, Orlandini A, Sacchelli L et al. Outcome of acute hepatitis $C$ is related to virus-specific CD4 function and maturation of antiviral memory CD8 responses. Hepatology 2006; 44: 126-139.

44 Lucas M, Ulsenheimer A, Pfafferot K, Heeg MH, Gaudieri S, Gruner N et al. Tracking virus-specific CD4+ $\mathrm{T}$ cells during and after acute hepatitis C virus infection. PLoS One 2007; 2: e649.

45 Sugimoto K, Ikeda F, Stadanlick J, Nunes FA, Alter HJ, Chang KM. Suppression of HCV-specific T cells without differential hierarchy demonstrated ex vivo in persistent HCV infection. Hepatology 2003; 38: 1437-1448.

46 Boettler T, Spangenberg HC, Neumann-Haefelin C, Panther E, Urbani S, Ferrari $C$ et al. T cells with a $C D 4+C D 25+$ regulatory phenotype suppress in vitro proliferation of virus-specific CD8+ T cells during chronic hepatitis C virus infection. J Virol 2005; 79: $7860-7867$

47 Hou X, Song J, Su J, Huang D, Gao W, Yan J et al. CD4(+)Foxp3(+) Tregs protect against innate immune cell-mediated fulminant hepatitis in mice. Mol Immunol 2015; 63: 420-427.

48 Shin EC, Park SH, Demino M, Nascimbeni M, Mihalik K, Major M et al. Delayed induction, not impaired recruitment, of specific CD8(+) T cells causes the late onset of acute hepatitis C. Gastroenterology 2011; 141: 686-695.
49 Shoukry NH, Grakoui A, Houghton M, Chien DY, Ghrayeb J, Reimann KA et al. Memory CD8+ T cells are required for protection from persistent hepatitis C virus infection. J Exp Med 2003; 197: 1645-1655.

50 Bengsch B, Seigel B, Ruhl M, Timm J, Kuntz M, Blum HE et al. Coexpression of PD-1, 2B4, CD160 and KLRG1 on exhausted $\mathrm{HCV}$-specific CD8+ $\mathrm{T}$ cells is linked to antigen recognition and $\mathrm{T}$ cell differentiation. PLoS Pathog 2010; 6: e1000947.

51 Spangenberg HC, Viazov S, Kersting N, Neumann-Haefelin C, McKinney D, Roggendorf $\mathrm{M}$ et al. Intrahepatic CD8+ T-cell failure during chronic hepatitis C virus infection. Hepatology 2005; 42: 828-837.

52 Wedemeyer H, He XS, Nascimbeni M, Davis AR, Greenberg HB, Hoofnagle JH et al. Impaired effector function of hepatitis $C$ virusspecific CD8+ T cells in chronic hepatitis $\mathrm{C}$ virus infection. $J$ Immunol 2002; 169: 3447-3458.

53 Martin B, Hennecke N, Lohmann V, Kayser A, Neumann-Haefelin C, Kukolj $\mathrm{G}$ et al. Restoration of HCV-specific CD8+ T cell function by interferon-free therapy. J Hepatol 2014; 61: 538-543.

54 Accapezzato D, Francavilla V, Paroli M, Casciaro M, Chircu LV, Cividini $A$ et al. Hepatic expansion of a virus-specific regulatory CD8 (+) T cell population in chronic hepatitis C virus infection. J Clin Invest 2004; 113: 963-972.

55 Kasprowicz V, Schulze Zur Wiesch J, Kuntzen T, Nolan BE, Longworth S, Berical A et al. High level of PD-1 expression on hepatitis $\mathrm{C}$ virus (HCV)-specific CD8+ and CD4+ T cells during acute HCV infection, irrespective of clinical outcome. J Virol 2008; 82: 3154-3160.

56 Radziewicz H, Ibegbu CC, Fernandez ML, Workowski KA, Obideen K, Wehbi $\mathrm{M}$ et al. Liver-infiltrating lymphocytes in chronic human hepatitis $C$ virus infection display an exhausted phenotype with high levels of PD-1 and low levels of CD127 expression. J Virol 2007; 81: 2545-2553.

57 Penna A, Pilli M, Zerbini A, Orlandini A, Mezzadri S, Sacchelli L et al. Dysfunction and functional restoration of HCV-specific CD8 responses in chronic hepatitis C virus infection. Hepatology 2007; 45: 588-601.

58 Golden-Mason L, Palmer B, Klarquist J, Mengshol JA, Castelblanco N, Rosen HR. Upregulation of PD-1 expression on circulating and intrahepatic hepatitis C virus-specific CD8+ T cells associated with reversible immune dysfunction. J Virol 2007; 81: 9249-9258.

59 McMahan RH, Golden-Mason L, Nishimura MI, McMahon BJ, Kemper M, Allen TM et al. Tim-3 expression on PD-1+ HCVspecific human CTLs is associated with viral persistence, and its blockade restores hepatocyte-directed in vitro cytotoxicity. J Clin Invest 2010; 120: 4546-4557.

60 Golden-Mason L, Palmer BE, Kassam N, Townshend-Bulson L, Livingston S, McMahon BJ et al. Negative immune regulator Tim-3 is overexpressed on $T$ cells in hepatitis $C$ virus infection and its blockade rescues dysfunctional CD4+ and CD8+ T cells. J Virol 2009; 83: 9122-9130.

61 Nakamoto N, Cho H, Shaked A, Olthoff K, Valiga ME, Kaminski M et al. Synergistic reversal of intrahepatic HCV-specific CD8 T cell exhaustion by combined PD-1/CTLA-4 blockade. PLoS Pathog 2009; 5: e1000313.

62 May S, Ngui SL, Collins S, Lattimore S, Ramsay M, Tedder RS et al. Molecular epidemiology of newly acquired hepatitis $\mathrm{C}$ infections in England 2008-2011: genotype, phylogeny and mutation analysis. J Clin Virol 2015; 64: 6-11.

63 Lafaro KJ, Demirjian AN, Pawlik TM. Epidemiology of hepatocellular carcinoma. Surg Oncol Clin N Am 2015; 24: 1-17.

$64 \mathrm{Lin} \mathrm{CL}, \mathrm{Kao} \mathrm{JH}$. Risk stratification for hepatitis B virus related hepatocellular carcinoma. J Gastroenterol Hepatol 2013; 28: 10-17.

65 Miroux C, Vausselin T, Delhem N. Regulatory T cells in HBV and HCV liver diseases: implication of regulatory $T$ lymphocytes in the control of immune response. Expert Opin Biol Ther 2010; 10: 1563-1572.

$66 \mathrm{Wu} \mathrm{H}$, Chen P, Liao R, Li YW, Yi Y, Wang JX et al. Intratumoral regulatory $\mathrm{T}$ cells with higher prevalence and more suppressive activity in hepatocellular carcinoma patients. J Gastroenterol Hepatol 2013; 28: 1555-1564.

67 Unitt E, Marshall A, Gelson W, Rushbrook SM, Davies S, Vowler SL et al. Tumour lymphocytic infiltrate and recurrence of hepatocellular carcinoma following liver transplantation. J Hepatol 2006; 45: 246-253. 
68 Thimme R, Neagu M, Boettler T, Neumann-Haefelin C, Kersting N, Geissler $\mathrm{M}$ et al. Comprehensive analysis of the alpha-fetoproteinspecific CD8+ $\mathrm{T}$ cell responses in patients with hepatocellular carcinoma. Hepatology 2008; 48: 1821-1833.

69 Harimoto H, Shimizu M, Nakagawa Y, Nakatsuka K, Wakabayashi A, Sakamoto $\mathrm{C}$ et al. Inactivation of tumor-specific CD8(+) CTLs by tumor-infiltrating tolerogenic dendritic cells. Immunol Cell Biol 2013; 91: 545-555.

70 Carulli L, Anzivino C. Telomere and telomerase in chronic liver disease and hepatocarcinoma. World J Gastroenterol 2014; 20: 6287-6292.

71 Satow R, Shitashige M, Kanai Y, Takeshita F, Ojima H, Jigami T et al. Combined functional genome survey of therapeutic targets for hepatocellular carcinoma. Clin Cancer Res 2010; 16: 2518-2528.

72 Komori H, Nakatsura T, Senju S, Yoshitake Y, Motomura Y, Ikuta Y et al. Identification of HLA-A2- or HLA-A24-restricted CTL epitopes possibly useful for glypican-3-specific immunotherapy of hepatocellular carcinoma. Clin Cancer Res 2006; 12: 2689-2697.

$73 \mathrm{Xu} \mathrm{H}$, Gu N, Liu ZB, Zheng M, Xiong F, Wang SY et al. NY-ESO-1 expression in hepatocellular carcinoma: a potential new marker for early recurrence after surgery. Oncol Lett 2012; 3: 39-44.

74 Bricard G, Bouzourene H, Martinet O, Rimoldi D, Halkic N, Gillet M et al. Naturally acquired MAGE-A10- and SSX-2-specific CD8+ T cell responses in patients with hepatocellular carcinoma. J Immunol 2005; 174: 1709-1716.

75 Yang ZQ, Yang ZY, Zhang LD, Ping B, Wang SG, Ma KS et al. Increased liver-infiltrating CD8+FoxP3+ regulatory $T$ cells are associated with tumor stage in hepatocellular carcinoma patients. Hum Immunol 2010; 71: 1180-1186.

76 Alisa A, Ives A, Pathan AA, Navarrete CV, Williams R, Bertoletti A et al. Analysis of CD4+ T-Cell responses to a novel alpha-fetoproteinderived epitope in hepatocellular carcinoma patients. Clin Cancer Res 2005; 11: 6686-6694.

77 Witkowski M, Spangenberg HC, Neumann-Haefelin C, Buttner N, Breous $\mathrm{E}$, Kersting $\mathrm{N}$ et al. Lack of ex vivo peripheral and intrahepatic alpha-fetoprotein-specific CD4+ responses in hepatocellular carcinoma. Int J Cancer 2011; 129: 2171-2182.

78 Kalathil S, Lugade AA, Miller A, Iyer R, Thanavala Y. Higher frequencies of GARP(+)CTLA-4(+)Foxp3(+) T regulatory cells and myeloid-derived suppressor cells in hepatocellular carcinoma patients are associated with impaired T-cell functionality. Cancer Res 2013; 73: 2435-2444

79 Kobayashi N, Hiraoka N, Yamagami W, Ojima H, Kanai Y, Kosuge T et al. FOXP3+ regulatory $\mathrm{T}$ cells affect the development and progression of hepatocarcinogenesis. Clin Cancer Res 2007; 13: 902-911.

80 Unitt E, Rushbrook SM, Marshall A, Davies S, Gibbs P, Morris LS et al. Compromised lymphocytes infiltrate hepatocellular carcinoma: the role of T-regulatory cells. Hepatology 2005; 41: 722-730.

81 Greten TF, Ormandy LA, Fikuart A, Hochst B, Henschen S, Horning M et al. Low-dose cyclophosphamide treatment impairs regulatory T cells and unmasks AFP-specific CD4+ T-cell responses in patients with advanced HCC. J Immunother 2010; 33: 211-218.

82 Manigold T, Racanelli V. T-cell regulation by CD4 regulatory T cells during hepatitis $\mathrm{B}$ and $\mathrm{C}$ virus infections: facts and controversies. Lancet Infect Dis 2007; 7: 804-813.

83 Shen Y, Wei Y, Wang Z, Jing Y, He H, Yuan J et al. TGF-beta regulates hepatocellular carcinoma progression by inducing Treg cell polarization. Cell Physiol Biochem 2015; 35: 1623-1632.

84 Shen $\mathrm{P}$, Wang $\mathrm{A}$, He M, Wang Q, Zheng S. Increased circulating Lin (-/low) CD33(+) HLA-DR(-) myeloid-derived suppressor cells in hepatocellular carcinoma patients. Hepatol Res 2014; 44: 639-650.

85 Schrader J. The role of MDSCs in hepatocellular carcinoma-in vivo veritas? J Hepatol 2013; 59: 921-923.

$86 \mathrm{Hu} \mathrm{CE}$, Gan J, Zhang RD, Cheng YR, Huang GJ. Up-regulated myeloid-derived suppressor cell contributes to hepatocellular carcinoma development by impairing dendritic cell function. Scand J Gastroenterol 2011, 156-164.

87 Hoechst B, Voigtlaender T, Ormandy L, Gamrekelashvili J, Zhao F, Wedemeyer $\mathrm{H}$ et al. Myeloid derived suppressor cells inhibit natural killer cells in patients with hepatocellular carcinoma via the NKp3O receptor. Hepatology 2009, 799-807.

88 Hoechst B, Ormandy LA, Ballmaier M, Lehner F, Kruger C, Manns MP et al. A new population of myeloid-derived suppressor cells in hepatocellular carcinoma patients induces CD4(+)CD25(+)Foxp3(+) T cells. Gastroenterology 2008; 135: 234-243.

89 Han Y, Chen Z, Yang Y, Jiang Z, Gu Y, Liu Y et al. Human CD14+ CTLA-4+ regulatory dendritic cells suppress $\mathrm{T}$-cell response by cytotoxic T-lymphocyte antigen-4-dependent IL-10 and indoleamine-2,3-dioxygenase production in hepatocellular carcinoma. Hepatology 2014; 59: 567-579.

90 Wang BJ, Bao JJ, Wang JZ, Wang $\mathrm{Y}$, Jiang M, Xing MY et al. Immunostaining of PD-1/PD-Ls in liver tissues of patients with hepatitis and hepatocellular carcinoma. World J Gastroenterol 2011; 17: 3322-3329.

91 Shi F, Shi M, Zeng Z, Qi RZ, Liu ZW, Zhang JY et al. PD-1 and PD-L1 upregulation promotes CD8(+) T-cell apoptosis and postoperative recurrence in hepatocellular carcinoma patients. Int J Cancer 2011; 128: 887-896.

92 Gehring AJ, Ho ZZ, Tan AT, Aung MO, Lee KH, Tan KC et al. Profile of tumor antigen-specific CD8 T cells in patients with hepatitis B virus-related hepatocellular carcinoma. Gastroenterology 2009; 137: 682-690.

93 Zeng Z, Shi F, Zhou L, Zhang MN, Chen Y, Chang XJ et al. Upregulation of circulating PD-L1/PD-1 is associated with poor post-cryoablation prognosis in patients with HBV-related hepatocellular carcinoma. PLoS One 2011; 6: e23621.

94 Gao Q, Wang XY, Qiu SJ, Yamato I, Sho M, Nakajima Y et al. Overexpression of PD-L1 significantly associates with tumor aggressiveness and postoperative recurrence in human hepatocellular carcinoma. Clin Cancer Res 2009; 15: 971-979.

95 Umemoto Y, Okano S, Matsumoto Y, Nakagawara H, Matono R, Yoshiya S et al. Prognostic impact of programmed cell death 1 ligand 1 expression in human leukocyte antigen class I-positive hepatocelIular carcinoma after curative hepatectomy. J Gastroenterol 2015; 50: 65-75.

96 Fujiwara K, Higashi $T$, Nouso K, Nakatsukasa H, Kobayashi $Y$, Uemura $\mathrm{M}$ et al. Decreased expression of B7 costimulatory molecules and major histocompatibility complex class-I in human hepatocellular carcinoma. J Gastroenterol Hepatol 2004; 19: 1121-1127.

97 Rigopoulou EI, Bogdanos DP. Is primary biliary cirrhosis rare or common? The truth lies somewhere in between. Liver Int 2014; 34: e165-e167.

98 Griffiths L, Dyson JK, Jones DE. The new epidemiology of primary biliary cirrhosis. Semin Liver Dis 2014; 34: 318-328.

99 Beuers U, Gershwin ME, Gish RG, Invernizzi P, Jones DE, Lindor K et al. Changing nomenclature for PBC: From 'cirrhosis' to 'cholangitis'. Hepatology 2015; 62: 1620-1622.

100 Wang L, Wang FS, Chang C, Gershwin ME. Breach of tolerance: primary biliary cirrhosis. Semin Liver Dis 2014; 34: 297-317.

101 Chang CH, Chen YC, Yu YH, Tao MH, Leung PS, Ansari AA et al. Innate immunity drives xenobiotic-induced murine autoimmune cholangitis. Clin Exp Immunol 2014; 177: 373-380.

102 Chang CH, Chen YC, Zhang W, Leung PS, Gershwin ME, Chuang YH. Innate immunity drives the initiation of a murine model of primary biliary cirrhosis. PloS One 2015; 10: e0121320.

103 Cordell HJ, Han Y, Mells GF, Li Y, Hirschfield GM, Greene CS et al. International genome-wide meta-analysis identifies new primary biliary cirrhosis risk loci and targetable pathogenic pathways. Nat Commun 2015; 6: 8019.

104 Dong M, Li J, Tang R, Zhu P, Qiu F, Wang C et al. Multiple genetic variants associated with primary biliary cirrhosis in a Han Chinese population. Clin Rev Allergy Immunol 2015; 48: 316-321.

105 Kurth MJ, Yokoi T, Gershwin ME. Halothane-induced hepatitis: paradigm or paradox for drug-induced liver injury. Hepatology 2014; 60: 1473-1475.

106 Lleo A, Zhang W, Zhao M, Tan Y, Bernuzzi F, Zhu B et al. DNA methylation profiling of the $X$ chromosome reveals an aberrant demethylation on CXCR3 promoter in primary biliary cirrhosis. Clin Epigenetics 2015; 7: 61.

107 Norman GL, Yang CY, Ostendorff HP, Shums Z, Lim MJ, Wang J et al. Anti-kelch-like 12 and anti-hexokinase 1: novel autoantibodies in primary biliary cirrhosis. Liver Int 2015; 35: 642-651.

108 Tana MM, Shums Z, Milo J, Norman GL, Leung PS, Gershwin ME et al. The significance of autoantibody changes over time in primary biliary cirrhosis. Am J Clin Pathol 2015; 144: 601-606. 
109 Tomiyama T, Yang GX, Zhao M, Zhang W, Tanaka H, Wang J et al. The modulation of co-stimulatory molecules by circulating exosomes in primary biliary cirrhosis. Cell Moll Immunol 2015; e-pub ahead of print 21 September 2015; doi:10.1038/cmi.2015.86.

110 Wang J, Yang GX, Tsuneyama K, Gershwin ME, Ridgway WM, Leung PS. Animal models of primary biliary cirrhosis. Semin Liver Dis 2014; 34: 285-296.

$111 \mathrm{Li}$ Y, Wang W, Tang L, He X, Yan X, Zhang X et al. Chemokine (C-X-C motif) ligand 13 promotes intrahepatic chemokine (C-X-C motif) receptor 5+ lymphocyte homing and aberrant B-cell immune responses in primary biliary cirrhosis. Hepatology 2015; 61: 1998-2007.

112 Lleo A, Zhang W, McDonald WH, Seeley EH, Leung PS, Coppel RL et al. Shotgun proteomics: identification of unique protein profiles of apoptotic bodies from biliary epithelial cells. Hepatology 2014; 60: 1314-1323.

113 Zhang J, Zhang W, Leung PS, Bowlus CL, Dhaliwal S, Coppel RL et al. Ongoing activation of autoantigen-specific B cells in primary biliary cirrhosis. Hepatology 2014; 60: 1708-1716.

114 Lleo A, Bowlus CL, Yang GX, Invernizzi P, Podda M, Van de Water J et al. Biliary apotopes and anti-mitochondrial antibodies activate innate immune responses in primary biliary cirrhosis. Hepatology 2010; 52: 987-998.

115 Rong G, Zhong R, Lleo A, Leung PS, Bowlus CL, Yang GX et al. Epithelial cell specificity and apotope recognition by serum autoantibodies in primary biliary cirrhosis. Hepatology 2011; 54: 196-203.

116 Kita H, Lian ZX, Van de Water J, He XS, Matsumura S, Kaplan M et al. Identification of HLA-A2-restricted $\mathrm{CD} 8(+)$ cytotoxic T cell responses in primary biliary cirrhosis: $T$ cell activation is augmented by immune complexes cross-presented by dendritic cells. J Exp Med 2002; 195: 113-123.

117 Colucci G, Schaffner F, Paronetto F. In situ characterization of the cell-surface antigens of the mononuclear cell infiltrate and bile duct epithelium in primary biliary cirrhosis. Clin Immunol Immunopathol 1986; 41: 35-42.

118 Kita H, Matsumura S, He XS, Ansari AA, Lian ZX, Van de Water J et al. Quantitative and functional analysis of PDC-E2-specific autoreactive cytotoxic $\mathrm{T}$ lymphocytes in primary biliary cirrhosis. J Clin Invest 2002; 109: 1231-1240.

119 Wakabayashi K, Yoshida K, Leung PS, Moritoki Y, Yang GX, Tsuneyama $\mathrm{K}$ et al. Induction of autoimmune cholangitis in nonobese diabetic (NOD).1101 mice following a chemical xenobiotic immunization. Clin Exp Immunol 2009; 155: 577-586.

120 Wakabayashi K, Lian ZX, Leung PS, Moritoki Y, Tsuneyama K, Kurth MJ et al. Loss of tolerance in C57BL/6 mice to the autoantigen E2 subunit of pyruvate dehydrogenase by a xenobiotic with ensuing biliary ductular disease. Hepatology 2008; 48: 531-540.

121 Ambrosini YM, Yang GX, Zhang W, Tsuda M, Shu S, Tsuneyama K et al. The multi-hit hypothesis of primary biliary cirrhosis: polyinosinic-polycytidylic acid (poly I:C) and murine autoimmune cholangitis. Clin Exp Immunol 2011; 166: 110-120.

122 Yang GX, Lian ZX, Chuang YH, Moritoki Y, Lan RY, Wakabayashi K et al. Adoptive transfer of $\mathrm{CD} 8(+) \mathrm{T}$ cells from transforming growth factor beta receptor type II (dominant negative form) induces autoimmune cholangitis in mice. Hepatology 2008; 47: 1974-1982.

123 Salas JT, Banales JM, Sarvide S, Recalde S, Ferrer A, Uriarte I et al. Ae2a,b-deficient mice develop antimitochondrial antibodies and other features resembling primary biliary cirrhosis. Gastroenterology 2008; 134: 1482-1493.

124 Yao Y, Yang W, Yang YQ, Ma HD, Lu FT, Li L et al. Distinct from its canonical effects, deletion of IL-12p40 induces cholangitis and fibrosis in interleukin-2Ralpha(-/-) mice. Journal of autoimmunity 2014; 51: 99-108.

125 Hsu W, Zhang W, Tsuneyama K, Moritoki Y, Ridgway WM, Ansari AA et al. Differential mechanisms in the pathogenesis of autoimmune cholangitis versus inflammatory bowel disease in interleukin-2Ralpha (-/-) mice. Hepatology 2009; 49: 133-140.

126 Kawata K, Yang GX, Ando Y, Tanaka H, Zhang W, Kobayashi Y et al. Clonality, activated antigen-specific CD8(+) T cells, and development of autoimmune cholangitis in dnTGFbetaRII mice. Hepatology 2013; 58: 1094-1104.
127 Shimoda S, Nakamura M, Ishibashi H, Hayashida K, Niho Y. HLA DRB4 0101-restricted immunodominant T cell autoepitope of pyruvate dehydrogenase complex in primary biliary cirrhosis: evidence of molecular mimicry in human autoimmune diseases. J Exp Med 1995; 181: 1835-1845.

128 Van de Water J, Ansari A, Prindiville T, Coppel RL, Ricalton N, Kotzin BL et al. Heterogeneity of autoreactive $\mathrm{T}$ cell clones specific for the E2 component of the pyruvate dehydrogenase complex in primary biliary cirrhosis. J Exp Med 1995; 181: 723-733.

129 Shimoda S, Miyakawa H, Nakamura M, Ishibashi H, Kikuchi K, Kita $\mathrm{H}$ et al. CD4 T-cell autoreactivity to the mitochondrial autoantigen PDC-E2 in AMA-negative primary biliary cirrhosis. J Autoimmun 2008; 31: 110-115.

130 Lan RY, Salunga TL, Tsuneyama K, Lian ZX, Yang GX, Hsu W et al. Hepatic IL-17 responses in human and murine primary biliary cirrhosis. J Autoimmun 2009; 32: 43-51.

131 Yang CY, Ma X, Tsuneyama K, Huang S, Takahashi T, Chalasani NP et al. IL-12/Th1 and IL-23/Th17 biliary microenvironment in primary biliary cirrhosis: implications for therapy. Hepatology 2014; 59: 1944-1953.

132 Lan RY, Cheng C, Lian ZX, Tsuneyama K, Yang GX, Moritoki Y et al. Liver-targeted and peripheral blood alterations of regulatory $T$ cells in primary biliary cirrhosis. Hepatology 2006; 43: 729-737.

133 Aoki CA, Roifman CM, Lian ZX, Bowlus CL, Norman GL, Shoenfeld Y et al. IL-2 receptor alpha deficiency and features of primary biliary cirrhosis. J Autoimmun 2006; 27: 50-53.

134 Tanaka H, Zhang W, Yang GX, Ando Y, Tomiyama T, Tsuneyama K et al. Successful immunotherapy of autoimmune cholangitis by adoptive transfer of forkhead box protein $3(+)$ regulatory T cells. Clin Exp Immunol 2014; 178: 253-261.

135 Huang W, Kachapati K, Adams D, Wu Y, Leung PS, Yang GX et al. Murine autoimmune cholangitis requires two hits: cytotoxic KLRG1 (+) CD8 effector cells and defective T regulatory cells. J Autoimmun 2014; 50: 123-134.

136 Wang YH, Yang W, Yang JB, Jia YJ, Tang W, Gershwin ME et al. Systems biologic analysis of $T$ regulatory cells genetic pathways in murine primary biliary cirrhosis. J Autoimmun 2015; 59: 26-37.

137 Yang JB, Wang YH, Yang W, Lu FT, Ma HD, Zhao ZB et al. Successful treatment of murine autoimmune cholangitis by parabiosis: Implications for hematopoietic therapy. J Autoimmun 2015; 66: 108-117.

138 Wang L, Sun X, Qiu J, Cai Y, Ma L, Zhao P et al. Increased numbers of circulating ICOS(+) follicular helper T and CD38(+) plasma cells in patients with newly diagnosed primary biliary cirrhosis. Dig Dis Sci 2015; 60: 405-413.

139 Wang L, Sun Y, Zhang Z, Jia Y, Zou Z, Ding J et al. CXCR5+ CD4+ $T$ follicular helper cells participate in the pathogenesis of primary biliary cirrhosis. Hepatology 2015; 61: 627-638.

140 Chuang YH, Lan RY, Gershwin ME. The immunopathology of human biliary cell epithelium. Semin Immunopathol 2009; 31: 323-331.

141 Shimoda S, Harada K, Niiro H, Taketomi A, Maehara Y, Tsuneyama K et al. CX3CL1 (fractalkine): a signpost for biliary inflammation in primary biliary cirrhosis. Hepatology 2010; 51: 567-575.

142 Alabraba EB, Lai V, Boon L, Wigmore SJ, Adams DH, Afford SC. Coculture of human liver macrophages and cholangiocytes leads to CD40-dependent apoptosis and cytokine secretion. Hepatology 2008; 47: 552-562.

143 Lleo A, Shimoda S, Ishibashi H, Gershwin ME. Primary biliary cirrhosis and autoimmune hepatitis: apotopes and epitopes. J Gastroenterol 2011; 46 (Suppl 1): 29-38.

144 Lleo A, Liao J, Invernizzi P, Zhao M, Bernuzzi F, Ma L et al. Immunoglobulin $\mathrm{M}$ levels inversely correlate with CD40 ligand promoter methylation in patients with primary biliary cirrhosis. Hepatology 2012; 55: 153-160.

145 Tanaka H, Yang GX, Iwakoshi N, Knechtle SJ, Kawata K, Tsuneyama $\mathrm{K}$ et al. Anti-CD40 ligand monoclonal antibody delays the progression of murine autoimmune cholangitis. Clin Exp Immunol 2013; 174: 364-371.

146 Dhirapong A, Yang GX, Nadler S, Zhang W, Tsuneyama K, Leung P et al. Therapeutic effect of cytotoxic $T$ lymphocyte antigen 4/immunoglobulin on a murine model of primary biliary cirrhosis. Hepatology 2013; 57: 708-715. 
147 Floreani A, Franceschet I, Cazzagon N, Spinazze A, Buja A, Furlan P et al. Extrahepatic autoimmune conditions associated with primary biliary cirrhosis. Clin Rev Allergy Immunol 2015; 48: 192-197.

148 Floreani A, Motta R, Cazzagon N, Franceschet I, Roncalli M, Del Ross $T$ et al. The overlap syndrome between primary biliary cirrhosis and primary sclerosing cholangitis. Dig Liver Dis 2015; 47: 432-435.

149 Floreani A, Spinazze A, Caballeria L, Reig A, Cazzagon N, Franceschet I et al. Extrahepatic malignancies in primary biliary cirrhosis: a comparative study at two European centers. Clin Rev Allergy Immunol 2015; 48: 254-262.

150 Rong G, Wang H, Bowlus CL, Wang C, Lu Y, Zeng Z et al. Incidence and risk factors for hepatocellular carcinoma in primary biliary cirrhosis. Clin Rev Allergy Immunol 2015; 48: 132-141.

151 Huang X, Wu H, Lu Q. The mechanisms and applications of T cell vaccination for autoimmune diseases: a comprehensive review. Clin Rev Allergy Immunol 2014; 47: 219-233.

152 Seldin MF. The genetics of human autoimmune disease: a perspective on progress in the field and future directions. J Autoimmun 2015; 64: 1-12.

153 Webb GJ, Hirschfield GM. Using GWAS to identify genetic predisposition in hepatic autoimmunity. J Autoimmun 2015; 66: 25-39.

154 Webb GJ, Siminovitch KA, Hirschfield GM. The immunogenetics of primary biliary cirrhosis: a comprehensive review. J Autoimmun 2015; 64: 42-52.

155 Beuers U, Gershwin ME. Unmet challenges in immune-mediated hepatobiliary diseases. Clin Rev Allergy Immunol 2015; 48: 127-131.

156 Czaja AJ. Diagnosis and management of autoimmune hepatitis. Clin Liver Dis 2015; 19: 57-79.

157 Czaja AJ. Cryptogenic chronic hepatitis and its changing guise in adults. Dig Dis Sci 2011; 56: 3421-3438.

158 Cancado EL, Abrantes-Lemos CP, Terrabuio DR. The importance of autoantibody detection in autoimmune hepatitis. Front Immunol 2015; 6: 222.

159 Liberal R, Grant CR, Mieli-Vergani G, Vergani D. Autoimmune hepatitis: a comprehensive review. J Autoimmun 2013; 41 : 126-139.

160 Taubert R, Hardtke-Wolenski M, Noyan F, Wilms A, Baumann AK, Schlue J et al. Intrahepatic regulatory T cells in autoimmune hepatitis are associated with treatment response and depleted with current therapies. J Hepatol 2014; 61: 1106-1114.

161 Miao Q, Bian Z, Tang R, Zhang $\mathrm{H}$, Wang Q, Huang $\mathrm{S}$ et al. Emperipolesis mediated by CD8 $T$ cells is a characteristic histopathologic feature of autoimmune hepatitis. Clin Rev Allergy Immunol 2015; 48: 226-235.

162 Ikeda A, Aoki N, Kido M, Iwamoto S, Nishiura H, Maruoka R et al. Progression of autoimmune hepatitis is mediated by IL-18-producing dendritic cells and hepatic CXCL9 expression in mice. Hepatology 2014; 60: 224-236.

163 Aoki N, Kido M, Iwamoto S, Nishiura H, Maruoka R, Tanaka J et al. Dysregulated generation of follicular helper $\mathrm{T}$ cells in the spleen triggers fatal autoimmune hepatitis in mice. Gastroenterology 2011; 140: 1322-1333.

164 Kido M, Watanabe N, Okazaki T, Akamatsu T, Tanaka J, Saga K et al. Fatal autoimmune hepatitis induced by concurrent loss of naturally arising regulatory T cells and PD-1-mediated signaling. Gastroenterology 2008; 135: 1333-1343.

165 Longhi MS, Hussain MJ, Mitry RR, Arora SK, Mieli-Vergani G, Vergani $\mathrm{D}$ et al. Functional study of $\mathrm{CD} 4+\mathrm{CD} 25+$ regulatory $T$ cells in health and autoimmune hepatitis. J Immunol 2006; 176: 4484-4491.

166 Liberal R, Grant CR, Holder BS, Ma Y, Mieli-Vergani G, Vergani D et al. The impaired immune regulation of autoimmune hepatitis is linked to a defective galectin-9/tim-3 pathway. Hepatology 2012; 56: 677-686.

167 Zhao L, Tang Y, You Z, Wang Q, Liang S, Han X et al. Interleukin-17 contributes to the pathogenesis of autoimmune hepatitis through inducing hepatic interleukin-6 expression. PLoS One 2011; 6: e18909

168 Singer BD, King LS, D'Alessio FR. Regulatory T cells as immunotherapy. Front Immunol 2014; 5: 46.
169 Maruoka R, Aoki N, Kido M, Iwamoto S, Nishiura H, Ikeda A et al. Splenectomy prolongs the effects of corticosteroids in mouse models of autoimmune hepatitis. Gastroenterology 2013; 145: 209-220.

170 Borsellino G, Kleinewietfeld M, Di Mitri D, Sternjak A, Diamantini A, Giometto $\mathrm{R}$ et al. Expression of ectonucleotidase CD39 by Foxp3+ Treg cells: hydrolysis of extracellular ATP and immune suppression. Blood 2007; 110: 1225-1232.

171 Kobie JJ, Shah PR, Yang L, Rebhahn JA, Fowell DJ, Mosmann TR. $T$ regulatory and primed uncommitted CD4 $T$ cells express CD73, which suppresses effector CD4 T cells by converting 5'-adenosine monophosphate to adenosine. J Immunol 2006; 177: 6780-6786.

172 Deaglio S, Dwyer KM, Gao W, Friedman D, Usheva A, Erat A et al. Adenosine generation catalyzed by CD39 and CD73 expressed on regulatory T cells mediates immune suppression. J Exp Med 2007; 204: 1257-1265.

173 Grant CR, Liberal R, Holder BS, Cardone J, Ma Y, Robson SC et al. Dysfunctional CD39(POS) regulatory $T$ cells and aberrant control of T-helper type 17 cells in autoimmune hepatitis. Hepatology 2014; 59: 1007-1015.

174 Longhi MS, Ma Y, Bogdanos DP, Cheeseman P, Mieli-Vergani G, Vergani D. Impairment of $\mathrm{CD} 4(+) \mathrm{CD} 25(+)$ regulatory T-cells in autoimmune liver disease. J Hepatol 2004; 41: 31-37.

175 Ferri S, Longhi MS, De Molo C, Lalanne C, Muratori P, Granito A et al. A multifaceted imbalance of $T$ cells with regulatory function characterizes type 1 autoimmune hepatitis. Hepatology 2010; 52: 999-1007.

176 Peiseler M, Sebode M, Franke B, Wortmann F, Schwinge D, Quaas A et al. FOXP3+ regulatory $T$ cells in autoimmune hepatitis are fully functional and not reduced in frequency. J Hepatol 2012; 57: 125-132.

177 Muratori L, Longhi MS. The interplay between regulatory and effector $T$ cells in autoimmune hepatitis: Implications for innovative treatment strategies. J Autoimmun 2013; 46: 74-80.

178 Hammerich L, Tacke F. Role of gamma-delta $T$ cells in liver inflammation and fibrosis. World J Gastrointest Pathophysiol 2014; 5: 107-113.

179 Liu X, Jiang X, Liu R, Wang L, Qian T, Zheng Y et al. B cells expressing CD11b effectively inhibit CD4+ T-cell responses and ameliorate experimental autoimmune hepatitis in mice. Hepatology 2015; 62: 1563-1575.

180 Bai L, Zhang W, Tan L, Yang H, Ge M, Zhu C et al. Hepatitis B virus hijacks CTHRC1 to evade host immunity and maintain replication. J. Mol Cell Biol 2015; 7: 543-556.

181 Yang DR, Zhu HZ. Hepatitis C virus and antiviral innate immunity: who wins at tug-of-war? World J Gastroenterol 2015; 21: 3786-3800.

182 Holz L, Rehermann B. T cell responses in hepatitis C virus infection: historical overview and goals for future research. Antiviral Res 2015; 114: 96-105.

183 Montano-Loza AJ, Czaja AJ. Cell mediators of autoimmune hepatitis and their therapeutic implications. Dig Dis Sci 2015; 60: 1528-1542.

184 Isogawa M, Tanaka Y. Immunobiology of hepatitis B virus infection. Hepatol Res 2015; 45: 179-189.

185 Manns MP, Lohse AW, Vergani D. Autoimmune hepatitisUpdate 2015. J Hepatol 2015; 62: S100-S111.

186 Dardalhon V, Korn T, Kuchroo VK, Anderson AC. Role of Th1 and Th17 cells in organ-specific autoimmunity. J Autoimmun 2008; 31: 252-256.

187 Harrington LE, Hatton RD, Mangan PR, Turner H, Murphy TL, Murphy KM et al. Interleukin 17-producing CD4+ effector T cells develop via a lineage distinct from the T helper type 1 and 2 lineages. Nat Immunol 2005; 6: 1123-1132.

188 Del Prete G, De Carli M, Almerigogna F, Giudizi MG, Biagiotti R, Romagnani S. Human IL-10 is produced by both type 1 helper (Th1) and type 2 helper (Th2) T cell clones and inhibits their antigenspecific proliferation and cytokine production. J Immunol 1993; 150: 353-360.

189 Korn T, Bettelli E, Oukka M, Kuchroo VK. IL-17 and Th17 cells. Annu Rev Immunol 2009; 27: 485-517.

190 Bettelli E, Carrier Y, Gao W, Korn T, Strom TB, Oukka M et al. Reciprocal developmental pathways for the generation of pathogenic effector TH17 and regulatory T cells. Nature 2006; 441: 235-238. 
191 Suh WK. Life of T follicular helper cells. Mol Cells 2015; 38 : 195-201.

192 Webb GJ, Hirschfield GM. Follicles, germinal centers, and immune mechanisms in primary biliary cirrhosis. Hepatology 2015; 61: 424-427.

193 Fletcher JM, Lonergan R, Costelloe L, Kinsella K, Moran B, O'Farrelly $\mathrm{C}$ et al. CD39+Foxp3+ regulatory T cells suppress pathogenic Th17 cells and are impaired in multiple sclerosis. J Immunol 2009; 183: 7602-7610.

194 Sebastiani S, Allavena P, Albanesi C, Nasorri F, Bianchi G, Traidl C et al. Chemokine receptor expression and function in CD4+ T lymphocytes with regulatory activity. In J Immunol 2001, 996-1002.

195 Mittrucker HW, Visekruna A, Huber M. Heterogeneity in the differentiation and function of CD8(+) T cells. Arch Immunol Ther Exp (Warsz) 2014; 62: 449-458.

196 Hinrichs CS, Kaiser A, Paulos CM, Cassard L, Sanchez-Perez L, Heemskerk B et al. Type 17 CD8+ T cells display enhanced antitumor immunity. Blood 2009; 114: 596-599.

197 Sinha S, Itani FR, Karandikar NJ. Immune regulation of multiple sclerosis by CD8+ T cells. Immunol Res 2014; 59: 254-265.

198 Boer MC, van Meijgaarden KE, Joosten SA, Ottenhoff TH. CD8+ regulatory $\mathrm{T}$ cells, and not $\mathrm{CD} 4+\mathrm{T}$ cells, dominate suppressive phenotype and function after in vitro live Mycobacterium bovis-BCG activation of human cells. PLoS One 2014; 9: e94192.

199 Wu Y, Wu W, Wong WM, Ward E, Thrasher AJ, Goldblatt D et al. Human gamma delta T cells: a lymphoid lineage cell capable of professional phagocytosis. J Immunol 2009; 183: 5622-5629.

200 Kenna T, Golden-Mason L, Norris S, Hegarty JE, O'Farrelly C, Doherty DG. Distinct subpopulations of gamma delta $T$ cells are present in normal and tumor-bearing human liver. Clin Immunol 2004; 113: 56-63.

201 Hoh A, Dewerth A, Vogt F, Wenz J, Baeuerle PA, Warmann SW et al. The activity of gammadelta $T$ cells against paediatric liver tumour cells and spheroids in cell culture. Liver Int 2013; 33 : 127-136.

202 Ajuebor MN, Jin Y, Gremillion GL, Strieter RM, Chen Q, Adegboyega PA. GammadeltaT cells initiate acute inflammation and injury in adenovirus-infected liver via cytokine-chemokine cross talk. J Virol 2008; 82: 9564-9576.

$203 \mathrm{Lu} \mathrm{Y}$, Wang X, Yan W, Wang $\mathrm{H}$, Wang $\mathrm{M}$, Wu $\mathrm{D}$ et al. Liver TCRgammadelta(+) CD3(+) CD4(-) CD8(-) T cells contribute to murine hepatitis virus strain 3-induced hepatic injury through a TNF-alpha-dependent pathway. Mol Immunol 2012; 52: 229-236.

204 Rhodes KA, Andrew EM, Newton DJ, Tramonti D, Carding SR. A subset of IL-10-producing gammadelta $T$ cells protect the liver from Listeria-elicited, CD8(+) T cell-mediated injury. Eur J Immunol 2008; 38: 2274-2283.

205 Hammerich L, Bangen JM, Govaere O, Zimmermann HW, Gassler N, Huss $S$ et al. Chemokine receptor CCR6-dependent accumulation of gammadelta $T$ cells in injured liver restricts hepatic inflammation and fibrosis. Hepatology 2014; 59: 630-642.

cc) (i) $(\Theta$ This work is licensed under a Creative Commons Attribution-NonCommercial-NoDerivs 4.0 International License. The images or other third party material in this article are included in the article's Creative Commons license, unless indicated otherwise in the credit line; if the material is not included under the Creative Commons license, users will need to obtain permission from the license holder to reproduce the material. To view a copy of this license, visit http://creativecommons.org/licenses/by-nc-nd/4.0/ 